\title{
Genetic, Biochemical and Clinical Insights into Primary Congenital Glaucoma
}

\author{
${ }^{1}$ Muneeb Faiq, ${ }^{2}$ Reetika Sharma, ${ }^{3}$ Rima Dada, ${ }^{4}$ Kuldeep Mohanty, ${ }^{5}$ Daman Saluja, ${ }^{6}$ Tanuj Dada
}

\begin{abstract}
Glaucoma is an irreversible form of optic neuropathy in which the optic nerve suffers damage in a characteristic manner with optic nerve cupping and retinal ganglion cell death. Primary congenital glaucoma (PCG) is an idiopathic irreversible childhood blinding disorder which manifests at birth or within the first year of life. PCG presents with a classical triad of symptoms (viz epiphora, photophobia and blepharospasm) though there are many additional symptoms, including large eye ball and hazy cornea. The only anatomical anomaly found in PCG is trabecular meshwork (TM) dysgenesis. PCG is an inheritable disease with established genetic etiology. It transmits through autosomal recessive mode. A number of cases are sporadic also. Mutations in many genes have been found to be causative in PCG and many are yet to be found. Mutations in cytochrome P4501B1 (CYP1B1) gene have been found to be the predominant cause of PCG. Other genes that have been implicated in PCG etiology are myocilin, Forkhead-related transcription factor $\mathrm{C} 1$ (FOXC1) and latent transforming growth factor beta-binding protein 2 (LTBP2). Mutations in these genes have been reported from many parts of the world. In addition to this, mitochondrial genome mutations are also thought to be involved in its pathogenesis. There appears to be some mechanism involving more than one genetic factor. In this review, we will discuss the various clinical, biochemical and genetic aspects of PCG. We emphasize that etiology of PCG does not lie in a single gene or genetic factor. Research needs to be oriented into a direction where gene-gene interactions, ocular embryology, ophthalmic metabolism and systemic oxidative status need to be studied in order to understand this disorder. We also accentuate the need for ophthalmic genetic facilities in all ophthalmology setups.
\end{abstract}

Keywords: Glaucoma, Primary congenital glaucoma, Genetics, CYP1B1, Myocilin.

How to cite this article: Faiq M, Sharma R, Dada R, Mohanty K, Saluja D, Dada T. Genetic, Biochemical and Clinical Insights into Primary Congenital Glaucoma. J Current Glau Prac 2013;7(2):66-84.

\section{Source of support: Nil}

Conflict of interest: None declared

\section{INTRODUCTION}

Glaucoma (pronunciation: glaw-ko'me), ${ }^{1}$ derived from Greek glaukos (meaning bluish-green gleam) ${ }^{2}$ is a term referring to a collection of related disorders with complex optic nerve atrophy ${ }^{3}$ and characteristic loss of larger retinal ganglion cells (RGC) ${ }^{4,5}$ leading to a consequent carbon copy pattern of loss of visual field and vision. ${ }^{6}$ The bluish green gleam was initially observed during dilated pupil eye examinations. ${ }^{7}$ Glaucoma has been nicknamed as 'the sneak thief of sight' and is characterized by those ocular conditions in which the intraocular pressure (IOP) is too high for the normal functioning of the optic nerve head. Previously, it was thought that glaucoma is the disease of the lens and hence the term was used for cataract. ${ }^{7}$ Later, the term buphthalmos found its way into literature which meant the enlargement of the ocular globe that resembled the eye of an ox (Greek bous means ox). ${ }^{8}$ Increase in the aqueous humor accumulation in the anterior chamber was recognized as an important clinical feature of glaucoma. ${ }^{8}$ It was then Adolf Weber who in 1856 elaborated the glaucomatous cupping of the optic disk. ${ }^{8}$ Glaucoma is the second largest cause of blindness in the world affecting an estimated population of 60 million. ${ }^{9,10}$ It has been estimated that there are 1.5 to 2 million blind children in the world and a majority of them live in developing countries. ${ }^{11}$ With regards to Indian scenario, Balasubramanian et al estimated that $1.8 \%$ of the Indian population is blind and $0.15 \%$ suffers from glaucoma. ${ }^{12}$ Once glaucomatous blindness is precipitated, there is no known treatment to refurbish vision. As a matter of fact, blindness from glaucoma is preventable in almost all cases. What is required for this prevention is early detection and prompt treatment. Early diagnosis with genetic counseling and proper molecular workout is likely to bring down the prevalence of glaucomatous blindness. ${ }^{13}$ If obstetricians make it a routine to observe the eyes of the neonate; early diagnosis on childhood glaucomas can be enhanced and consequent blindness hampered. There have been a few attempts to classify glaucomas but no classification system is absolute. However, glaucoma is traditionally classified on the basis of etiology (primary and secondary), anatomy of anterior chamber (open angle and closed angle), time of onset (infantile, juvenile and adult) and pathogenesis (congenital and acquired). Nevertheless, modern classification system classifies this disorder into three major groups viz (a) primary open angle glaucoma (POAG; OMIM 137760), (b) primary congenital glaucoma (PCG; OMIM 231300) and (c) primary angle closure glaucoma (PACG; no OMIM entry). Figure 1 depicts the general outline of the classification of glaucoma. The etiology of a majority of glaucoma cases is unknown ${ }^{14}$ but many factors like increase in IOP, obstruction to aqueous humor drainage, development anomalies of anterior chamber ${ }^{15,16}$ and genetic susceptibility have been implicated. One of the prime focuses in our laboratory is to 


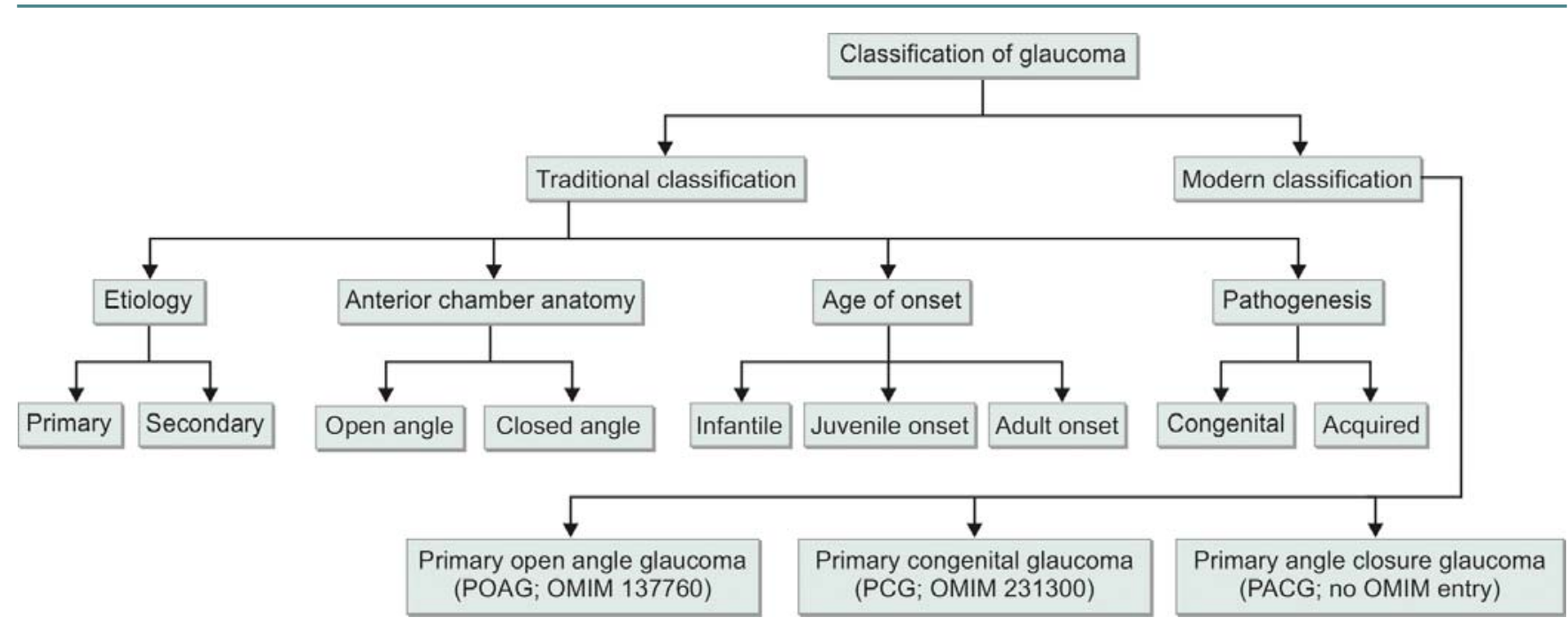

Fig. 1: General classification of glaucoma

understand, appreciate and get an insight into the genetic etiopathology of the disease and its correlation with the so developed phenotype. We endeavor to correlate gene mutations with severity of the phenotype, age of onset, response to medical (IOP lowering drugs like $\beta$-blockers) and surgical therapy (trabeculectomy/trabeculotomy) giving considerable insight into the prognosis and management of glaucoma. Genotype phenotype correlations are likely to help clinicians manage the disease better and the genetic counselor to help inflicted families with the disease management. ${ }^{13}$

\section{PRIMARY CONGENITAL GLAUCOMA}

Primary congenital glaucoma (PCG; OMIM 231300; provided in the public domain by National center for Biotechnology Information, Bethesda, MD) is an autosomal recessively inherited severe form of glaucoma resulting from obstruction in the aqueous humor drainage due to congenital developmental anomalies in anterior chamber angle/angle structures. ${ }^{17-19}$ It accounts for $22.2 \%$ of all pediatric glaucoma cases. Congenital buphthalmos has early history having been recognized since the time of Hippocrates (460377 BC), Celsus (1st century CE) and Galen (130-201 CE). Buphthalmos is a result of the distensibility of the neonatal eye ball. This distensibility in the neonatal eye ball is because of the high content of elastic fibers in sclera. The mechanism of buphthalmos includes global delocalized stretching of the sclera, optic nerve and the related structures due to increased IOP. ${ }^{20,21}$ The normal range for corneal diameter of a neonate is 10 to $10.5 \mathrm{~mm}$ which, owing to growth, increases by 0.5 to $1.0 \mathrm{~mm}$ in first year of life. ${ }^{22}$ Any increase in corneal diameter (>12 mm) in the first year of life is suggestive of PCG. ${ }^{21}$ Additionally, the optic nerve cupping being one of the hallmarks of glaucoma; in case of
PCG, the optic nerve changes are not similar to that of glaucomatous adults. Optic nerve cupping may progress fast and early in newborns and toddlers ${ }^{23,24}$ and can be reversible if normal IOP is restored well in time. ${ }^{25}$ On the other hand, glaucomatous optic nerve head damage is irreversible in adults. $^{24}$

PCG has its onset at as early as birth or manifests within first 3 years of life. ${ }^{26}$ It presents with a classical triad of symptoms viz epiphora (excessive tearing), photophobia (hypersensitivity to light) and blepharospasm (inflammation of the eyelids). ${ }^{21}$ Any combination of these symptoms are indicative (if not conclusive) of glaucoma. These symptoms are caused by the irritation of cornea leading to corneal epithelial edema and haze (clouding). Enlargement of eye (buphthalmos) is a result of increased IOP. The other findings include: (i) iris covering a variable portion of ciliary body and trabecular meshwork (TM), ${ }^{19,27}$ (ii) thickened trabecular beams in trabeculum ${ }^{28}$ as schematically depicted in Figure 2, (iii) juxtacanalicular meshwork with very small number of pores, ${ }^{29,30}$ (iv) absence of sinus venosus eye (i.e. Schlemm's canal) $)^{17,31}$ and (v) breaks in Descemet's membrane (Haab's striae). ${ }^{7}$ A collection of the symptoms of PCG are depicted in Table 1. The term PCG has been restricted to the cases where only anatomical defect observed is isolated trabecular dysgenesis. ${ }^{32}$ This is also referred to as isolated congenital glaucoma. ${ }^{33} \mathrm{~A}$ characteristic cloudiness or foggy manifestation of the cornea can be observed in early stages which appear before any breaks in the Descemet's membrane are visible. PCG comprises 4.2\% of all childhood blindness being bilateral in $80 \%$ of cases. PCG cases presented within first year of life form more than $80 \%$ out of which $25 \%$ are diagnosed in the neonatal period and about $60 \%$ within first 6 months of life. Being the most common pediatric glaucoma, PCG comprises more 


\begin{tabular}{ll}
\hline \multicolumn{1}{c}{ Table 1: Symptoms of PCG } \\
\multicolumn{1}{c}{ Classical triad of symptoms } \\
\hline Symptom & Description \\
\hline $\begin{array}{l}\text { 1. Epiphora } \\
\text { 2. Photophobia }\end{array}$ & $\begin{array}{l}\text { Excessive tearing } \\
\text { Hypersensitivity to light } \\
\text { Inflammation of eyelids }\end{array}$ \\
\hline \multicolumn{1}{c}{ Blepharospasm } & Additional signs and symptoms \\
\hline $\begin{array}{l}\text { 1. Enlargement of the eyeball (buphthalmos) } \\
\text { 2. Iris covering a variable portion of ciliary body and trabecular meshwork } \\
\text { 3. Juxtacanalicular with less number of pores } \\
\text { 4. Absence of Schlemm's canal (sinus venosus eye) }\end{array}$ & \\
5. Breaks in Descemet's membrane (Haab's striae) & \\
\hline
\end{tabular}
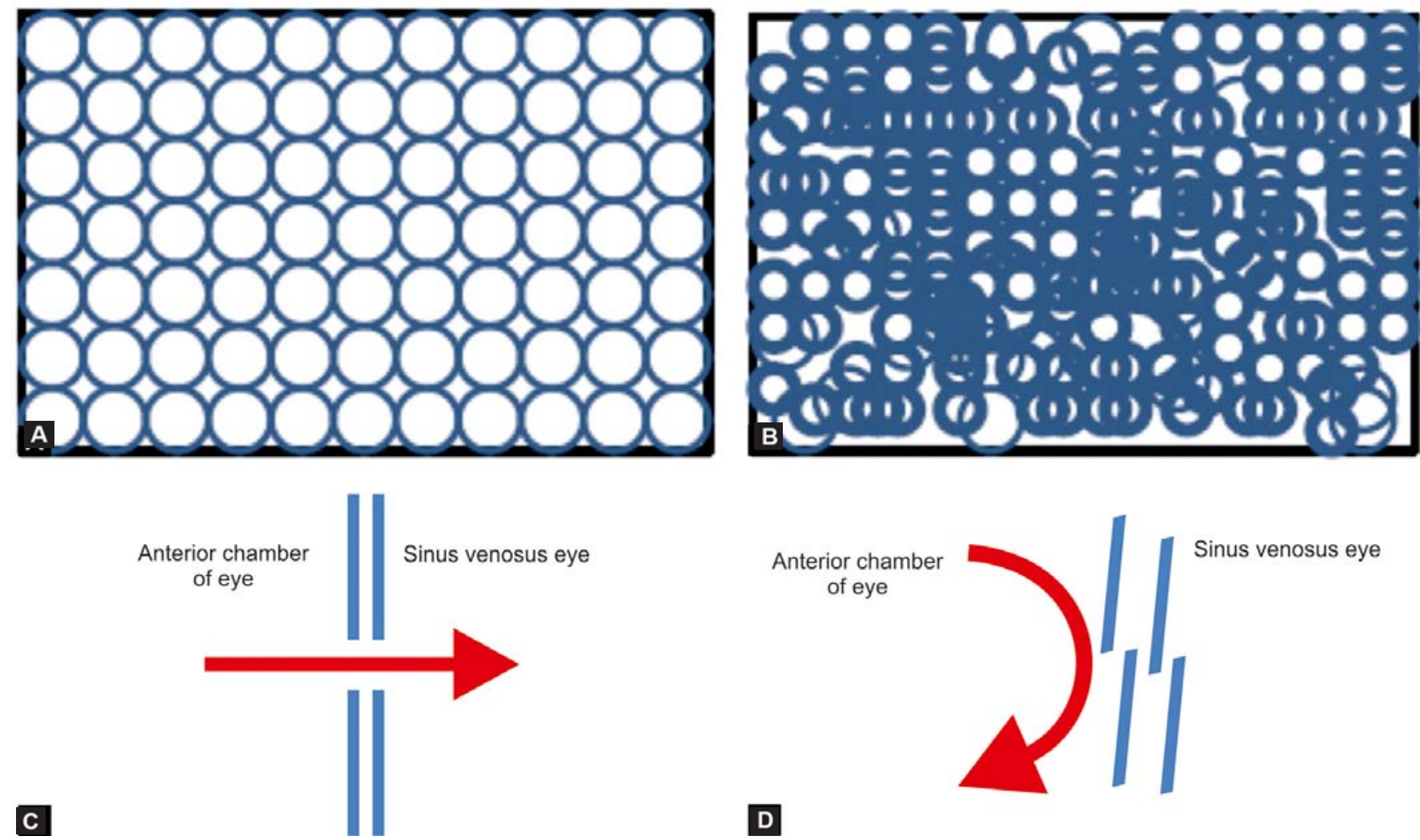

Figs 2A to D: Schematic representation of the trabecular meshwork dysgenesis and mechanism of IOP elevation: (A) Normal trabecular meshwork, (B) glaucomatous trabecular meshwork, (C) smooth unobstructed flow of aqueous humor across the trabecular meshwork, (D) obstruction in the aqueous flow and consequent build up of IOP

than $55 \%$ of primary pediatric glaucomas with expression and penetrance varying from 40 to $100 \%{ }^{34}$

\section{Genetics of PCG}

The first report on genetic predisposition to glaucomas was published in 1842 when Benedict observed two sisters suffering from glaucoma. ${ }^{35}$ Afterward, many reports came to the limelight suggesting a definite role of genetic factors. $^{36-38}$ PCG is inherited in an autosomal (of chromosomes other than sex chromosomes) recessive mode of transmission. Association of congenital glaucoma with chromosomal abnormalities of at least 17 different autosomes has also been reported in literature. ${ }^{39}$ Congenital glaucoma being associated with chromosomal aberrations has been well documented in many reports. ${ }^{40-42}$ To quote examples, congenital glaucoma with $22 \mathrm{p}+$ variant chromosome has been reported in a study of Indian population. ${ }^{42}$ Another study has observed various chromosomal anomalies, such as trisomy 8q22-qter/monosomy 9p23-qter in Australian population. ${ }^{43}$ Additionally, Mitchell et $\mathrm{al}^{44}$ has observed $4 \mathrm{q}$ deletion in Axenfeld-Rieger's syndrome (ARS). We have also reported $4 \mathrm{q}$ deletion in a case of ARS. ${ }^{45}$ Moore et al reported 11p deletion in aniridia (absence of iris). ${ }^{46}$

The genetic basis of PCG remains idiopathic but 13 chromosomal loci (GLC1A to GLC1N) for the POAG and 
Genetic, Biochemical and Clinical Insights into Primary Congenital Glaucoma

Table 2: Mapping and clinical features of PCG

\begin{tabular}{lclclc}
\hline Nomenclature & Chromosomal location & DNA marker region & Gene identified & Mode of inheritance & Penetrance \\
\hline GLC3A & 2p21-22 & D252186 and C251346 & CYP1B1 & Autosomal recessive & Severe \\
GLC3B & $1 \mathrm{p} 36$ & D151597 and D151176 & & Autosomal recessive & Severe \\
GLC3C & $14 q 24.3$ & D14553 & LTBP2 & Autosomal recessive & Severe \\
\hline
\end{tabular}

three chromosomal loci (GLC3A to GLC3C) for PCG have been mapped. Out of these 13, only 4 viz GLC1A (myocilin gene) and GLC1E (optineurin gene) for POAG and GLC3A (CYP1B1 gene) ${ }^{47-49}$ and GLC3C (LTBP2 gene) for PCG have been characterized. Independent studies by many researchers during the past few years have lead to the mapping of three distinct 'GLC' loci for PCG. 'GLC' is the nomenclature of the Human Genome Organization (HGO) for glaucoma. The numerals ' 1 ', ' 2 ' and ' 3 ' following 'GLC' refer to juvenile open angle glaucoma (JOAG), angle closure glaucoma and congenital glaucoma respectively. The letters 'A', 'B' and ' $\mathrm{C}$ ' following the numerals indicate the chronology (date-wise) in which the genes were mapped. Table 2 summarizes various aspects of currently known 'GLC' loci with their respective mode of inheritance and penetrance. PCG is thought to be transmitted as an autosomal recessive trait. ${ }^{50}$ This is because lower than expected number of cases have been observed and genetic heterogeneity has been postulated with support from linkage studies. ${ }^{51}$ The unequal sex distribution of PCG, however, points to some additional unknown factors. Majority of PCG cases are sporadic but 10 to $40 \%$ are familial and associated with consanguinity. ${ }^{34}$ The expression and penetrance of this disorder varies from 40 to $100 \%$. Up until now, three genetic loci have been mapped for PCG. ${ }^{52,53}$ PCG presents a differentially variable geographical distribution with lower occurrence in western countries and high prevalence in the middle-east and still higher prevalence in consanguineous societies like Slovakian gypsies ${ }^{54}$ and Saudi Arabians. The manifestations of PCG show a particular concordance in monozygotic twins and discordance in dizygotic twins. ${ }^{50}$ Prevalence of PCG ranges from one in 10,000 in Europe ${ }^{55}$ and one in 3,300 in Andhra Pradesh (Southern India) ${ }^{56}$ to one in 2,500 in middle-east (Saudi Arabia) and one in 1,250 in Roms (Gypsy population of Slovakia). ${ }^{55,57-59}$ Though transmitted through autosomal recessive mode as suggested by many reports, ${ }^{52,60-62}$ this mode of transmission of PCG has recently been questioned ${ }^{63}$ because of differential prevalence in different sexes. ${ }^{64}$ Prevalence among males accounts for $65 \%$ of total number of cases. ${ }^{65}$ In an early study from Japan females were, conversely, reported to be having higher prevalence. ${ }^{66}$ On the other hand, males and females were reported to be equally affected in Europe and
USA. ${ }^{67}$ In a study, on 616 cases of congenital glaucoma where patients were divided into two groups (one with sporadic cases and other with familial), it was observed that, in the first group there were $70 \%$ of males and the second group comprised of 58\% males. PCG has been shown to display a definite pattern of inheritance in 30 to $40 \%$ cases $^{67}$ but some investigators have reported familial incidence of only 11 to $14 \% .{ }^{68}$ There are, nonetheless, so many facts and observations that indicate the autosomal mode of transmission of PCG with a penetrance of 40 to $100 \%$. The autosomal recessive mode of PCG transmission has been demonstrated in rabbits ${ }^{69-71}$ and dogs. ${ }^{72}$ Intermediate inheritance has also been reported in rabbits. ${ }^{73}$ One more observation supporting the autosomal recessive means of inheritance is that, in PCG, the incidence of consanguinity of the parents overshoots $8 \% .^{74}$ There are so many studies that support this observation. ${ }^{68,75-78}$ Moreover, in most of the PCG cases, two or more siblings are affected with normal parents and descendents. ${ }^{68,74,76} \mathrm{~A}$ classical report by Gianferrari and his coinvestigators document two most characteristic pedigrees in which the first consisted of 11 cases of buphthalmos and two consanguineous marriages with three affected children out of four and two out of $12 .^{75}$ And, in case of the other pedigree, there were five cases of congenital glaucoma and two consanguineous marriages with two affected children out of four and one out of six. ${ }^{75}$ A peculiar finding in these pedigrees supporting autosomal recessive mode of inheritance is that the parents were phenotypically normal in all these cases. PCG is mostly sporadic with variable penetrance. ${ }^{7,33,68,75,79-83}$

These observations are thought to exist because of genetic heterogeneity. ${ }^{51,84}$ The genetic heterogeneity studies for PCG started in early 1990s and the first locus for PCG (GLC3A) was mapped to chromosomal location 2p21 in 1995 by Sarfarazi et al. ${ }^{60}$ The investigators described the involvement of this locus in 11 of the 17 Turkish families studied. They performed haplotype analysis and homozygosity mapping which led to the mapping of the diseased gene within $2.5 \mathrm{cM}$ interval flanked by two DNA marker regions viz D252186 and C251346. Since this was the first chromosomal locus identified to be associated with PCG, it was designated 'GLC3A' (GLC: glaucoma, 3: congenital, A: first locus identified) as per the nomenclature 
for HGO/Genome Database. Later studies done on Slovakian and Saudi Arabian population confirmed this finding. ${ }^{61,62}$ Since only 11 of the 17 Turkish families were found to be having involvement of 2p21 region in their disease phenotype, it was therefore, logical to think that at least one more locus existed to account for the remaining six families. On this premise, the investigators performed haplotype analysis of these six families and successfully mapped the disease locus of four of these families to the chromosomal location 1p36 within in gene interval of $3 \mathrm{cM}$. This locus was found to be flanked by two sets (six in total) of DNA marker regions viz D151597/D15485/D15228 and D151176/D15508/D15407. There are many tumor suppressor genes in this region. ${ }^{85}$ Being the second locus to be mapped, it was designated 'GLC3B'. ${ }^{2}$ A very large number of genes have been found to be located in 1p36 region but none has been postulated as a causative factor for PCG. This region is very prone to chromosomal aberrations resulting in many malignant diseases. Also, the neighboring regions of 1 p36 quite often participate in recombination events. ${ }^{86}$ Since the identification of genetic locus for two of the 17 families still remained, it meant that at least one more genetic locus remains to be mapped. The multigeneration pedigree analysis of one of those remaining two families revealed a third PCG locus with chromosomal location $14 q 24.3$ within a region 2.9-cM narrow. ${ }^{53}$ Being the third in the chronology of mapping, this locus was designated 'GLC3C'. Using the genome-wide scanning approach, the investigators were able to identify the DNA markers region D14553. Using additional DNA markers in haplotype analysis, it was found that all PCG patients shared DNA marker regions of homozygosity including D14542/ D145983/D1451020 and D14574.

\section{Polygenic Inheritance of PCG}

Before going on to discuss the genes involved and implicated in PCG, it forms a good rationale to add a note about its polygenic inheritance. PCG is not a unigenic etiological outcome but rather multifactorial genetic phenotype. Many genes (CYP1B1, MYOC, FOXC1, LTBP2, etc.) have been found to be involved in its etiology but there remains a great spectrum to be identified. Mutations in CYP1B1 gene account for a very little percentage of total number of PCG cases, it is logical for that reason to speculate about the role of other genes in PCG development and pathogenesis. There are a number of studies which suggest that the bequest of PCG is polygenic (involving more than one gene as an etiological factor). These genes may have functional interactions among themselves and may, for that reason, act in synergy with each other leading to the development of anterior chamber ocular structures. Any violation of the harmony anywhere in the functional muddle of these genes may give rise to anomalies in the anterior chamber anatomy and, therefore, to PCG. Polygenic inheritance can be explained via many reasons, such as variable penetrance observed in these cases and varied prevalence with respect to sex in different population. There are, however, some studies which suggest that there are no gender-wise differences in prevalence of PCG. ${ }^{82}$ As we will discuss in this review that many genes have been implicated in etiology of PCG, the polygenic etiology of this disorder is well confirmed. Functional interaction between CYP1B1 gene and MYOC gene further lends support to this.

\section{Cytochrome P450, Family 1, Subfamily B, Polypeptide 1 (CYP1B1) Gene and PCG}

The cytochrome P450 superfamily consists of as many as 70 gene families spanning across bacteria, yeasts, insects and vertebrates as well as plant kingdom. ${ }^{87}$ Fourteen mammalian families of P450 have been observed till date, out of which, five have been reported to have many subfamilies. Formerly, it was thought that cytochromeP4501B1 family is composed of two members viz CYP1A1 and CYP1A2. ${ }^{87}$ The genes of this family are ubiquitous in mammals and have comparable catabolic activities toward a great number of xenobiotics. CYP1B1 is the third member of this family which has been recently characterized. CYP1B1 gene (GenBank accession no. U56438), therefore, forms a member of the superfamily of drug metabolizing enzymes cytochrome-P450 (CYP450). The CYP450 family is inclusive of 58 functional genes in humans and 102 in mice. ${ }^{88}$ Initially, this gene was recognized as a dioxinresponsive cDNA clone. The activities of this gene against various xenobiotics and metabolic approaches toward many procarcinogens have been thoroughly explored. ${ }^{89}$ In one of the approaches, TCDD (2,3,7,8-tetrachlorodibenzo-pdioxin) responsive cDNA was isolated from a human keratinocyte cell line and established as a new cytochrome P450 superfamily member. ${ }^{89}$ The translation product of this gene designated as cytochrome P4501B1 (CYP1B1) has also been cloned and characterized from mouse ${ }^{90}$ and rat. ${ }^{91}$ It is interesting to note that the size of rodent and human CYP1B1 mRNA is almost equal (5.2 kB in mice and $5.1 \mathrm{kB}$ in humans). Furthermore, both rodent and human CYP1B1 code for a protein 543 amino acids long. CYP1B1 is constitutively expressed in adrenal glands, ovaries, testes and more than 15 other tissues of the body. Its expression can be upregulated by aromatic hydrocarbons, adrenocorticotropin and peptide hormones. ${ }^{89,92}$ This protein plays 
a pivotal role in metabolism of drugs and a wide range of xenobiotics. ${ }^{92}$ The tissue distribution pattern of this protein suggests its role in metabolism of steroid hormones ${ }^{92,93}$ at least indirectly. CYP1B1 gene was isolated and mapped to chromosomal location 2 p21-22 by Tang et al. ${ }^{94}$

In humans, the CYP1B1 gene consists of three exons (with open reading frame starting from exon II) and two introns and is $8.5 \mathrm{kB}$ long. These three exons are $371,1,044$ and 3,707 base pairs in length respectively. Conversely, the two introns are 390 and 3,032 base pairs long. Both the introns commence with the sequence GT... and end with the sequence ...AG. The upstream regions of introns are pyrimidine rich, the coding region of CYP1B1 gene starts at the 5' end of 2nd exon and ends within the last exon. The translation product of CYP1B1 gene is 543 amino acids (corresponding to 1,629 bases) long protein with 53 residue membrane bound $\mathrm{N}$-terminal, 10 residue proline rich hinge (contributing to the flexibility of the protein) and 480 amino acid long cytosolic globular domain. The carboxy terminal region of CYP1B1 is highly conserved suggesting a pivotal role of this region. The carboxy terminal of cytochrome p450 enzymes corresponds to a set of conserved core structures (CCS) for the heme-binding region essential for the normal functioning of this class of enzymes. Figure 3 illustrates a schematic diagram of CYP1B1 gene. The CYP1B1 is a single copy gene as confirmed by the southern analysis studies using DNA probes to all three exons. It differs significantly from its close relatives CYP1A1 in CYP1A2. CYP1A1 and CYP1A2 both have seven exons as against three in CYP1B1 with former being located on chromosome 15 and the latter on chromosome 2. CYP1B1 gene lacks a consensus TATA box in the promoter region and contains nine TCDD responsive enhancer regions (5'GCGTG-3') located within a $2.5 \mathrm{kB}$ upstream. Deletion analysis studies with chloramphenicol acetyltransferase reporter gene constructs containing 5'CYP1B1 genomic fragment indicated that an upstream region from $-1,002$ to -835 contains core binding motifs contributing to the TCDD inducible expression. CYP1B1 is expressed in many tissues including brain and breast secretary cells ${ }^{95}$ and almost in 15 other nonocular tissues. ${ }^{89}$ In its metabolic pathway, CYP1B1 generates molecular species which operate through some signaling pathways and regulate expression of a spectrum of genes implicated in growth, development and differentiation of different ocular structures. CYP1B1 gene product also metabolizes vitamin A in two steps to alltransretinal (aldehyde form) and all-transretinoic acid (carboxylic acid form). ${ }^{96}$ All-transretinoic acid is an effective morphogen and regulates in utero (fetal) development, growth and differentiation. ${ }^{97}$ The CYP450

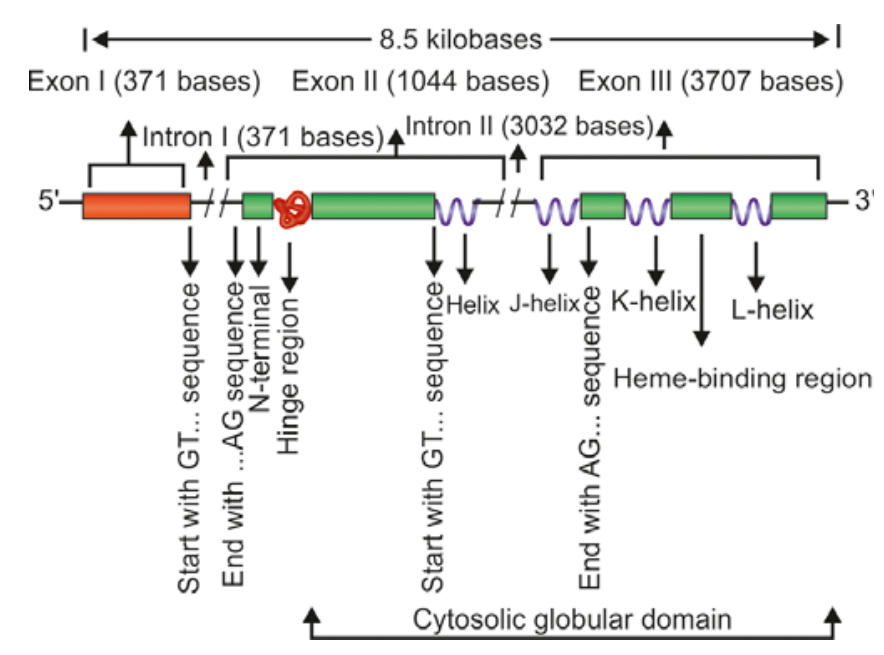

Fig. 3: Schematic representation of CYP1B1 gene

enzymes usually incorporate one atom of oxygen into its substrate creating hydroxyl $(\mathrm{OH})$, amino $\left(\mathrm{NH}_{2}\right)$ or carboxyl $(\mathrm{COOH})$ functional groups (oxidoreductase functions), therefore, possibly playing a role in mediating oxygenation of bio-organic species and consequently signal transduction..$^{98,99} \mathrm{CYP} 1 \mathrm{~B} 1$ is expressed in ciliary body, iris, retina and also in TM of the anterior segment chamber of the eye. ${ }^{100}$ However, recently some investigators have put a caveat and observed that CYP1B1 is not expressed in TM at any stage of eye development ${ }^{101}$ suggesting that $\mathrm{TM}$ maintenance is being carried out by exotic supply of CYP1B1 protein to TM. This fact may provide a premise in designing a recombinant CYP1B1 product and delivering it for therapeutic use for TM dysgenesis.

Although, three different loci for PCG have been identified but the CYP1B1 gene located in GLC3A region (chromosomal location 2p21) is the first and was until recently the only gene to be implicated in etiology and pathogenesis of PCG. ${ }^{102}$ This gene was identified using positional cloning and in situ hybridization. ${ }^{102}$ CYP1B1 gene mutations are one of the major etiologies behind PCG. Mutations in this gene have gained a lot interest from researchers and now ocular geneticists are reporting increasing number of mutations. Till date more than 500 PCG patients with mutations in various regions of CYP1B1 gene have been reported all over the world ${ }^{103}$ (Ni La et al, 2011). These mutations occur in variable frequencies and pathogenicities. Some pathogenic mutations (e.g. Gly368Stop) are extensively widespread while others (e.g. p.Gly252Arg, p.Gly367Arg and p.Pro370Leu) occur in varying prevalence in different population. Mutations in CYP1B1 gene are considered to be the most common cause of PCG. Table 3 enlists a comprehensive update of all the mutations in CYP1B1 gene in PCG patients with the exact mutation and aberration in the translation product. The table 
also indicates the mutation type against each. Our research group has reported CYP1B1 mutations in 32 of total 73 PCG patients. We have identified and reported novel mutations (six nonsynonymous and one synonymous) p.Leu24Arg, p.Phe190Leu, p.Gly329Asp ${ }^{104}$ p.Ile94X, p.His279Asp, p.Gln340His and p.Lys433Lys ${ }^{105}$ along with other mutations in CYP1B1 gene in PCG patients. Table 4 enlists the novel mutations reported by our laboratory with their corresponding GenBank accession numbers and likely effect on the corresponding protein function. Our study constitutes the first CYPIB1 mutational spectrum report for PCG from northern India. ${ }^{104}$

Mutations in CYP1B1 gene have been described as the main underlying genetic etiology for majority of PCG cases in Turkish and Saudi Arabian families. ${ }^{62}$ European, Canadian and Slovakian families suffering from PCG have also been report to harbor mutations in CYP1B1 gene. ${ }^{106}$ Figure 4 illustrates the worldwide distribution of CYP1B1 mutations in PCG patients and a comprehensive country wise list has been shown in Table 5 . A very large number of mutations in this gene have been reported with approximately 30\% insertions and deletion. ${ }^{34,62,102,107-113}$ The number of reports of allelic heterogeneity at GL3CA locus is increasing very fast. Three-dimensional model structure analyses have revealed that most of the nonsynonymous mutations affect the relatively conserved carboxyl half of the CYP1B1 protein leading to derangements in the core structure of the enzyme. ${ }^{114}$ This, therefore, makes a good rationale to think that these mutations affect the functional properties of the enzyme like substrate recognition, etc. Our studies, for this reason, are currently focused on functional characterization of CYP1B1 mutations. The CYP1B1 polymorphism is most likely to be conserved; however, some modulations are possible within certain limits. In Saudi Arabia, the mutations G61E accounts for almost $70 \%$ of the PCG cases. ${ }^{61,108,115}$ Interestingly, E387K mutation was found in 43 patients who could be traced to a common ancestor. ${ }^{115}$ Stoilov et al reported 4340delG mutation in $20.2 \%$ of PCG cases in Brazil. ${ }^{112}$ Till date, at least 147 different CYP1B1 mutations have been identified all over the world in 542 PCG patients ${ }^{103}$ and the list is growing with increasing number of reports. These include deletions, insertions missense, nonsense, frameshift as well as truncating mutations and a mutation in noncoding region of exon I. Table 3 gives a comprehensive update on the exon-wise distribution of CYP1B1 mutations in PCG patients. Studies suggest that the most severe phenotype is associated with the frameshift mutations. ${ }^{116}$ The mutational spectrum of CYP1B1 gene in different population and its consequent correlation with etiology and pathogenesis of PCG has lead to the idea that CYP1B1 enzyme is important for development of the anterior chamber of eye. CYP1B1 protein has been found to be present in higher levels in fetal ocular structure as compared to adult eye, therefore, lending support to the idea. Since ciliary body secretes metalloproteases (an

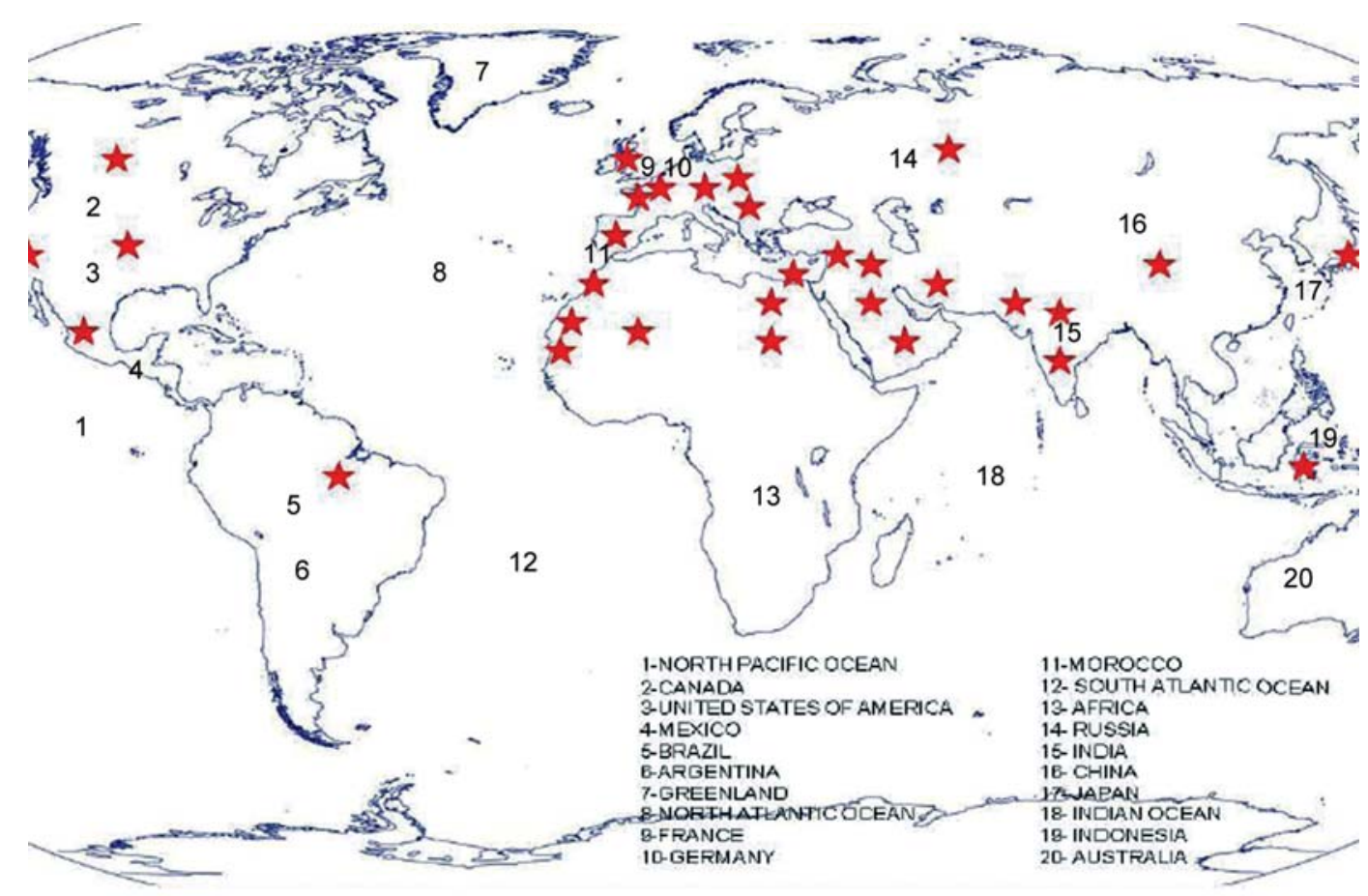

Fig. 4: Worldwide distribution of CYP1B1 mutations (as reported in literature) in PCG. The stars show the areas where CYP1B1 mutation have been reported in PCG patients 
Genetic, Biochemical and Clinical Insights into Primary Congenital Glaucoma

Table 3: Mutations found till date in CYP1B1 gene in PCG patients. Only mutations that manifest in the translation product have been listed

\begin{tabular}{|c|c|c|c|c|}
\hline Genomic position & Base alteration & Change in protein & Mutation type & Number of cases reported \\
\hline \multicolumn{5}{|c|}{ Exon I } \\
\hline g.3131 & $\mathrm{C}>\mathrm{T}$ & Noncoding region & Probably regulatory & 2 \\
\hline \multicolumn{5}{|c|}{ Exon II } \\
\hline g.3834 & Insertion A & Frameshift & Insertion & 11 \\
\hline g.3860 & $C>T$ & p.Q19X & Nonsense & 2 \\
\hline g.3876 & $T>G$ & p.L24R* & Missense & 2 \\
\hline g.3905 & Deletion 23bp & Deletion & Deletion in frame & 2 \\
\hline g.3913 & $\mathrm{C}>\mathrm{T}$ & p.Q37X & Nonsense & 1 \\
\hline g.3929 & $C>T$ & p.Q42X & Nonsense & 1 \\
\hline g.3956 & Insertion C & Frameshift & Insertion & 1 \\
\hline g.3960 & $C>T$ & p.P52L & Missense & 1 \\
\hline g.3964 & Deletion C & Frameshift & Deletion & 1 \\
\hline g.3972 & Deletion C & Frameshift & Deletion & 2 \\
\hline g.3976 & $\mathrm{G}>\mathrm{A}$ & p.W57X & Nonsense & 6 \\
\hline g.3976 & $\mathrm{G}>\mathrm{C}$ & p.W57C & Missense & 1 \\
\hline g.3979 & Deletion A & Frameshift & Deletion & 1 \\
\hline g.3985 & $C>G$ & p.160M & Missense & 1 \\
\hline g.3987 & $G>A$ & p.G61E & Missense & 207 \\
\hline g.3988 & Deletion A & Frameshift & Deletion & 2 \\
\hline g. 4004 & Deletion 8bp & Frameshift & Deletion & 1 \\
\hline g.4035 & $\mathrm{T}>\mathrm{C}$ & p.L77P & Missense & 2 \\
\hline g.4046 & $\mathrm{T}>\mathrm{A}$ & p.Y81N & Missense & 2 \\
\hline g.4048 & $C>A$ & p.Y81X & Nonsense & 2 \\
\hline g.4052 & Deletion G & Frameshift* & Deletion & 2 \\
\hline g.4081 & Deletion C & Frameshift & Deletion & 2 \\
\hline g.4089 & $\mathrm{T}>\mathrm{C}$ & p.V95A & Missense & 1 \\
\hline g.4122 & $C>A$ & p.A106D & Missense & 1 \\
\hline g. 4124 & $C>G$ & p.L107V & Missense & 4 \\
\hline g.4133 & $C>T$ & p.Q110X & Nonsense & 12 \\
\hline g.4148 & $\mathrm{G}>\mathrm{C}$ & p.A115P & Missense & 2 \\
\hline g.4154 & $C>T$ & p.R117W & Missense & 1 \\
\hline g.4155 & $\mathrm{G}>\mathrm{C}$ & p.R117P & Missense & 1 \\
\hline g.4157 & $C>T$ & p.P118S & Missense & 2 \\
\hline g.4168 & Insertion 18bp & Frameshift & Insertion & 1 \\
\hline g.4196 & Deletion 5bp & Frameshift & Deletion & 1 \\
\hline g.4200 & $\mathrm{T}>\mathrm{G}$ & p.M132R & Missense & 4 \\
\hline g.4206 & $\mathrm{T}>\mathrm{C}$ & p.F134S & Missense & 1 \\
\hline g.4236 & $A>C$ & p.Q144P & Missense & 1 \\
\hline g.4236 & $A>G$ & p.Q144R & Missense & 1 \\
\hline g.4238 & Deletion 10bp & Frameshift & Deletion & 4 \\
\hline g.4259/60 & Deletion AT( & Frameshift & Deletion & 1 \\
\hline g.4280 & $C>T$ & p.Q159X & Nonsense & 1 \\
\hline g.4292 & $\mathrm{C}>\mathrm{T}$ & p.R163C & Missense & 1 \\
\hline g.4306 & Insertion T & Frameshift & Insertion & 2 \\
\hline g.4322 & $G>A$ & p.E173K & Missense & 8 \\
\hline g.4322 & $\mathrm{G}>\mathrm{T}$ & p.E173x & Nonsense & 1 \\
\hline g.4330/31 & Deletion TG0 & Frameshift & Deletion & 3 \\
\hline g.4335 & $T>G$ & p.L177R & Missense & 2 \\
\hline g.4335 & $\mathrm{T}>\mathrm{C}$ & p.L177P & Missense & 1 \\
\hline g.4339 & Deletion G & Frameshift & Deletion & 24 \\
\hline g.4340 & Deletion G & Frameshift & Deletion & 34 \\
\hline g.4342 & Deletion G & Frameshift & Deletion & 1 \\
\hline g.4373 & $\mathrm{T}>\mathrm{C}$ & p.F190L* & Missense & 1 \\
\hline g.4375 & $C>A$ & p.F190L & Missense & 2 \\
\hline g.4379 & $\mathrm{G}>\mathrm{T}$ & p.D192Y & Missense & 1 \\
\hline g.4380 & $A>T$ & p.D192V & Missense & 4 \\
\hline g.4383 & $C>T$ & p.P193L & Missense & 4 \\
\hline g.4397 & $G>A$ & p.V198L & Missense & 2 \\
\hline g.4410 & $C>A$ & p.A202D & Missense & 1 \\
\hline g.4413 & $A>G$ & p.N203S & Missense & 1 \\
\hline g.4430 & $\mathrm{T}>\mathrm{C}$ & p.C209R & Missense & 1 \\
\hline g.4449 & $G>T$ & p.S215। & Missense & 3 \\
\hline g.4490 & $G>A$ & p.E229K & Missense & 29 \\
\hline
\end{tabular}




\begin{tabular}{|c|c|c|c|c|}
\hline g.4499 & $G>C$ & p.G232R & Missense & 1 \\
\hline g.4520 & $A>C$ & p.S239R & Missense & 4 \\
\hline g. 4523 & Deletion C & Frameshift & Deletion & 1 \\
\hline g.4530 & $\begin{array}{l}\text { Duplication 16/ } \\
\text { Deletion } 62\end{array}$ & Frameshift & Duplication and deletion & 1 \\
\hline g.4531 & Deletion 22 bp & Frameshift & Deletion & 1 \\
\hline g.4547 & $\mathrm{C}>\mathrm{T}$ & p.Q248X & Nonsense & 1 \\
\hline g.4578 & $C>A$ & p.F261L & Missense & 3 \\
\hline g.4589 & $\mathrm{G}>\mathrm{T}$ & p.E262X & Nonsense & 1 \\
\hline g.4602 & Deletion 9 bp & In frame deletion & Deletion & 4 \\
\hline g.4611 & Duplication 9 bp & Frameshift & Duplication & 2 \\
\hline g.4633 & Deletion C & Frameshift & Deletion & 2 \\
\hline g.4635 & Deletion $\mathrm{T}$ & Frameshift & Deletion & 5 \\
\hline g.4640 & $C>G$ & p.H279D* & Missense & 1 \\
\hline g.4645 & $C>A$ & p.C280X & Nonsense & 3 \\
\hline g.4646 & $\mathrm{G}>\mathrm{T}$ & p.E280X & Nonsense & 3 \\
\hline g.4650 & $G>A$ & p.S282N & Missense & 1 \\
\hline g.4664 & $\mathrm{G}>\mathrm{A}$ & p.A287S & Missense & 1 \\
\hline g.4668 & Insertion C & Frameshift & Insertion & 6 \\
\hline g.4673 & Insertion C & Frameshift & Insertion & 4 \\
\hline g.4677 & $A>G$ & p.D291G & Missense & 6 \\
\hline g.4680/813 & $T>A / G>A$ & p.M292K & Missense & 1 \\
\hline g.4761 & $A>G$ & p.N319s & Missense & 1 \\
\hline g.4763 & $\mathrm{G}>\mathrm{T}$ & p.V32L & Missense & 2 \\
\hline g.4776 & Insertion AT & Frameshift & Insertion & 4 \\
\hline g.4791 & $\mathrm{G}>\mathrm{T}$ & p.G329V & Missense & 5 \\
\hline g.4791 & $\mathrm{G}>\mathrm{A}$ & p.G329D* & Missense & 2 \\
\hline g.4793/94 & $\mathrm{G}>\mathrm{T} / \mathrm{C}>\mathrm{T}$ & p.A330F & Missense & 1 \\
\hline g.4812 & $C>A$ & p.S336Y & Missense & 1 \\
\hline g.4825 & $G>T$ & p.Q340H* & Missense & 1 \\
\hline g.4828 & $G>A$ & p.W341X & Nonsense & 1 \\
\hline g.4838 & Deletion CTC & In frame deletion & Deletion & 1 \\
\hline \multicolumn{5}{|c|}{ Intron-II-Exon-III junction } \\
\hline g.4849 & $\begin{array}{l}\text { Deletion Intron- } \\
\text { II-Exon-III }\end{array}$ & Frameshift & Deletion & 2 \\
\hline \multicolumn{5}{|c|}{ Exon-III } \\
\hline g.7899 & Deletion 12bp & In frame deletion & Deletion & 1 \\
\hline g.7900 & $C>T$ & p.R355X & Nonsense & 2 \\
\hline g.7900 & Deletion CG & Frameshift & Deletion & 4 \\
\hline g.7901 & Deletion 13bp & Frameshift & Deletion & 30 \\
\hline g.7925 & $\mathrm{T}>\mathrm{A}$ & p.V363D & Missense & 2 \\
\hline g.7927 & $G>A$ & p.V364M & Alternate frame & 17 \\
\hline g.7930 & $G>T$ & p.G365W & Missense & 2 \\
\hline g.7934 & Deletion G & Frameshift & Deletion & 2 \\
\hline g.7939 & $C>T$ & p.R368C & Missense & 3 \\
\hline g.7940 & $G>A$ & p.R368H & Missense & 87 \\
\hline g.7940 & $\mathrm{G}>\mathrm{T}$ & p.R368L & Missense & 2 \\
\hline g.7945 & Deletion C & Frameshift & Deletion & 2 \\
\hline g.7957 & $G>A$ & p.D374N & Missense & 8 \\
\hline g.7959 & $C>G$ & p.D374E & Missense & 2 \\
\hline g.7970 & $\mathrm{T}>\mathrm{A}$ & p.L378Q & Missense & 1 \\
\hline g.7990 & $\mathrm{C}>\mathrm{T}$ & p.L385F & Missense & 14 \\
\hline g.7996 & $G>A$ & p.E387K & Missense & 65 \\
\hline g.7999 & $G>A$ & p.A388T & Missense & 3 \\
\hline g.8005 & $C>T$ & p.R390C & Missense & 23 \\
\hline g.8005 & $C>A$ & p.R390S & Missense & 4 \\
\hline g.8006 & $\mathrm{G}>\mathrm{A}$ & p.R390H & Missense & 74 \\
\hline g.8033 & $T>G$ & p.I399s & Missense & 1 \\
\hline g.8034 & $\mathrm{C}>\mathrm{T}$ & p.P400S & Missense & 3 \\
\hline g.8037 & Duplication 10bp & Frameshift & Duplication & 39 \\
\hline g.8047 & Duplication 10bp & Frameshift & Duplication & 1 \\
\hline g.8104 & $\mathrm{A}>\mathrm{T}$ & p.N423Y & Missense & 1 \\
\hline g.8111 & Insertion G & Frameshift & Insertion & 2 \\
\hline g.8127 & $C>G$ & p.D430E & Missense & 1 \\
\hline g.8131 & $C>G$ & p.L432V & Missense & 1 \\
\hline
\end{tabular}




\begin{tabular}{|c|c|c|c|c|}
\hline g.8139 & $G>A$ & p.W434X & Nonsense & 1 \\
\hline g.8147 & $C>T$ & p.P437L & Missense & 7 \\
\hline g.8162 & $C>G$ & p.P442R & Missense & 1 \\
\hline g.8165 & $C>G$ & p.A443G & Missense & 3 \\
\hline g.8167 & $C>T$ & p.R444X & Nonsense & 1 \\
\hline g.8168 & $G>A$ & p.R444Q & Missense & 9 \\
\hline g.8170 & $\mathrm{T}>\mathrm{A}$ & p.F445I & Missense & 2 \\
\hline g.8171 & $\mathrm{T}>\mathrm{G}$ & p.F445C & Missense & 1 \\
\hline g.8171 & $\mathrm{T}>\mathrm{C}$ & p.F445S & Missense & 2 \\
\hline g.8182 & Deletion G & Frameshift & Deletion & 11 \\
\hline g.8209 & $\begin{array}{l}\text { Deletion } \\
\text { 5bp/insertion } \\
\text { 11bp } 4\end{array}$ & Frameshift & Deletion/insertion & 1 \\
\hline g.8214 & Duplication 27bp & Frameshift & Duplication & 3 \\
\hline g.8214/15 & Deletion AG & Frameshift & Deletion & 2 \\
\hline g.8234 & $\mathrm{G}>\mathrm{A}$ & p.G466D & Missense & 2 \\
\hline g.8240 & Duplication 27bp & Frameshift & Duplication & 2 \\
\hline g.8242 & $\mathrm{C}>\mathrm{T}$ & p.R469W & Missense & 53 \\
\hline g.8246 & $G>A$ & p.C470Y & Missense & 2 \\
\hline g.8249 & $T>G$ & p.I471S & Missense & 2 \\
\hline g.8297 & $\mathrm{T}>\mathrm{C}$ & p.L487P & Missense & 2 \\
\hline g.8329 & $A>G$ & p.N498D & Missense & 1 \\
\hline g.8333 & $A>G$ & p.E499G & Missense & 1 \\
\hline g.8341 & Deletion A & Frameshift & Deletion & 2 \\
\hline g.8354 & Deletion 20bp & Frameshift & Deletion & 2 \\
\hline g.8373 & Deletion 6bp & In frame deletion & Deletion & 2 \\
\hline g.8405 & $G>A$ & p.R523K & Missense & 4 \\
\hline \multicolumn{5}{|c|}{ Undefined } \\
\hline Not defined & Not defined & Not defined & Not defined & 89 \\
\hline $\begin{array}{l}\text { Total number of } \\
\text { mutation types }\end{array}$ & & $\begin{array}{l}147 \text { (excluding } \\
\text { unidentified types) }\end{array}$ & $\begin{array}{l}\text { Total number } \\
\text { of patients }\end{array}$ & 542 \\
\hline
\end{tabular}

*These mutations were first reported from our laboratory;

DAn example of double deletion; 2Duplication and deletion in the same gene; 3Double substitution; $\mathbf{4}$ Deletion and insertion in the same gene

Table 4: Novel mutation in CYP1B1 gene in PCG patients that we have reported

\begin{tabular}{llllll}
\hline Mutation & Codon change & Amino acid change & Mutation type & $\begin{array}{l}\text { GenBank } \\
\text { acc. number }\end{array}$ & Likely effect \\
\hline g. 38159965 T>G & CTG to CGG & p.Leu24Arg & Nonsynonymous & FJ815437 & Pathogenic \\
g. 38155466 C>A & TTC to TTA & p.Phe190Leu & Nonsynonymous & FJ815438 & Pathogenic \\
g. 38155050 G>A & GGC to GAC & p.Gly329Asp & Nonsynonymous & FJ815439 & Pathogenic \\
g. 38302285 Gdel & insSTOP & p.lle94X & Nonsense & GQ925803 & Pathogenic \\
g. 38301697 C > G & CAC to GAC & His279Asp & Nonsynonymous & GQ925804 & Pathogenic \\
g. 38301512 G>T & CAG to CAT & p.Gln340His & Nonsynonymous & GQ925805 & Probably pathogenic \\
g. 38298198 G>A & AAG to AAA & p.Lys433Lys & Synonymous & GQ925806 & Nonpathogenic \\
\hline
\end{tabular}

enzyme whose catalytic activity requires a metal ion), CYP1B1 having metabolic influence on these secretions can influence IOP. ${ }^{117}$ Additionally, CYP1B1 (-/-) mice (also designated as CYP1B1 null mice) have on the contrary of the belief been found to be nonglaucomatous with normal anterior chamber. But electron microscopy of the anterior chamber structure of such mice has revealed hypoplasia of the TM, abnormally placed basal lamina and iridocorneal adhesions. ${ }^{118}$ More recent reports have, on the other hand, reported elevated IOP in CYP1B1(-/-) mice. ${ }^{119}$ Also, CYP1B1 mutations in presence of tyrosinase (TYR) deficiency (129 x1/SvJ) develop into a more severe phenotype immediately suggesting TYR as a modifier gene. ${ }^{118}$ TYR deficiency is also found in patients with anterior segment dysgenesis (ASD) and albinism. ${ }^{120}$ Therefore, in addition to identifying other loci and genes as agents behind pathogenesis of PCG, gene-gene interaction studies might lead to proper understanding of the disease pathogenesis and consequently revealing probable mechanism for required therapy.

\section{Myocilin/TIGR Gene (Myocilin/Trabecular Meshwork Inducible Glucocorticoid Response Protein) and PCG}

MYOC gene belongs to the family of the soluble $\mathrm{N}$ ethylmaleimide sensitive factor attachment protein receptor 
Table 5: Geography/ethnicity-based distribution of mutations in CYP1B1 gene in PCG patients

\begin{tabular}{|c|c|c|}
\hline Country/ethnogeographic origin & Number of cases reported & References \\
\hline Algeria & 15 & 1130 \\
\hline Asia & 4 & 1482 \\
\hline \multirow[t]{3}{*}{ Brazil } & 26 & 53 \\
\hline & 4 & 149 \\
\hline & 9 & 150 \\
\hline Britain & 15 & 1513 \\
\hline Canadian & 2 & 152 \\
\hline \multirow[t]{5}{*}{ China } & 7 & 153 \\
\hline & 1 & 154 \\
\hline & 20 & 155 \\
\hline & 6 & 156 \\
\hline & 1 & 157 \\
\hline Ecuador & 2 & 158 \\
\hline Germany & 9 & 159 \\
\hline Gypsies & 7 & 160 \\
\hline Hispanic & 17 & 1064 \\
\hline \multirow[t]{9}{*}{ India } & 37 & 161 \\
\hline & 2 & 162 \\
\hline & 24 & 163 \\
\hline & 1 & 116 \\
\hline & 1 & 164 \\
\hline & 1 & 165 \\
\hline & 6 & 166 \\
\hline & 23 & 104 \\
\hline & 9 & 105 \\
\hline Indonesia & 6 & 1675 \\
\hline \multirow[t]{2}{*}{ Iran } & 72 & 168 \\
\hline & 13 & 169 \\
\hline Israel & 9 & 170 \\
\hline \multirow[t]{3}{*}{ Japan } & 13 & 110 \\
\hline & 2 & 107 \\
\hline & 4 & 171 \\
\hline Kuwait & 12 & 172 \\
\hline \multirow[t]{2}{*}{ Mexico } & 4 & 173 \\
\hline & 2 & 174 \\
\hline \multirow[t]{2}{*}{ Morocco } & 11 & 175 \\
\hline & 19 & 176 \\
\hline \multirow[t]{2}{*}{ Netherlands } & 1 & 177 \\
\hline & 1 & 178 \\
\hline Oman & 8 & 179 \\
\hline Pakistan & 3 & 180 \\
\hline Russia & 26 & 1816 \\
\hline \multirow[t]{3}{*}{ Saudi Arabia } & 24 & 62 \\
\hline & 10 & 108 \\
\hline & 5 & 1820 \\
\hline Slovak Gypsies & 20 & 115 \\
\hline \multirow[t]{2}{*}{ Spain } & 14 & 183 \\
\hline & 1 & 184 \\
\hline \multirow[t]{3}{*}{ Turkey } & 5 & 102 \\
\hline & 1 & 185 \\
\hline & 15 & 186 \\
\hline United States of America & 1 & 187 \\
\hline
\end{tabular}

(This study also included French and Portuguese patients; 2This study also included Hispanic, Middle Eastern and Caucasian patients; 3This study also included Italian and Indian patients; (4This study also included American, French, British and Turkish patients; (5This study also included Sudanese, Turkish and Italian patients; 6 This study also included Costa Rican, Turkish, German, Swiss, American and Saudi Arabian patients; $\boldsymbol{\nabla}$ This study also included Egyptian patients

(SNARE). The proteins of SNARE family function as vesicle trafficking and targeting factors thereby serving as molecular addresses on secretory vesicles. ${ }^{121}$ The MYOC gene codes for a protein that was initially named trabecular meshwork inducible glucocorticoid response protein (TIGR). This gene has been mapped to chromosomal locus 1q23-24 ${ }^{122}$ with physical map between four contiguous genes viz SELL, SELE, APT1LG1 and AT3. ${ }^{123}$ Owing to its similarities with bullfrog olfactomedin and Dictyostelium discoideum myosin as per the sequence analogy, this protein was named myocilin by Kubota et al. ${ }^{124}$ MYOC spans an approximate of $20 \mathrm{kB}$ and like CYP1B1 has three exons ${ }^{116-118}$ 
Genetic, Biochemical and Clinical Insights into Primary Congenital Glaucoma

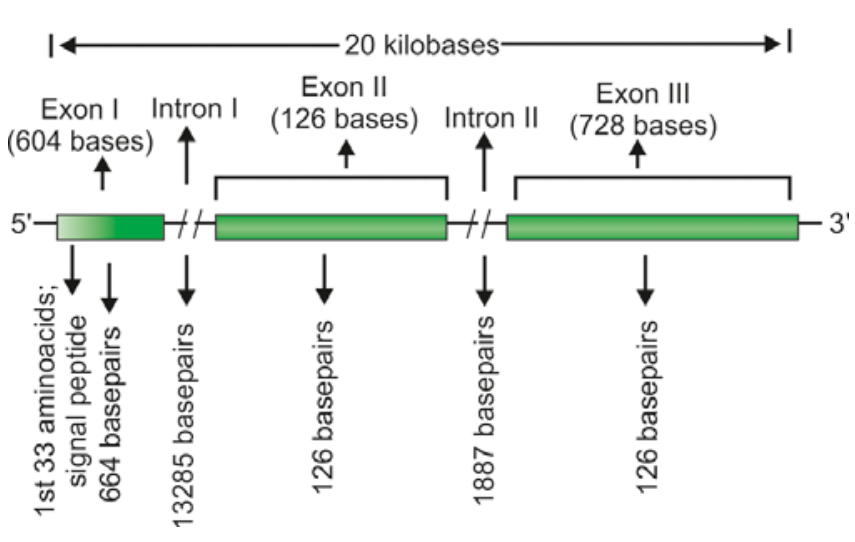

Fig. 5: Schematic representation of MYOC gene

with exon I comprising of 604 bases, exon II 126 and exon III 728 bases. A schematic representation of the MYOC gene is given in Figure 5. There are presumably a good number of transcription regulatory sequences identified in the upstream region of the MYOC gene. Three different polyadenylation sites have been identified to be positioned in the 3' untranslated region (UTR) of the gene occupying positions 1,714, 1,864 and 2,006 downstream from the putative start codon. Its anticipated open reading frame has two possible start (ATG) sites adjoining each other. The translation product of MYOC gene is a $55 \mathrm{kDa}$ olfactomedin-related secretory protein 504 amino acids long. ${ }^{125}$ In humans, the first 33 amino acids of this protein form a signal peptide and amino acids from 111 to 184 structure an alpha helical coiled region approximating the shape of myosin tail containing a leucine zipper motif involved in myocilin-myocilin interactions. Examination for hydrophobicity has interestingly revealed a hydrophobic region between amino acid 17 and 37, 426 and 244. The three amino acids at the carboxy terminal of human MYOC protein are serine, lysine and methionine which is a peroxisome targeting sequence in other proteins. ${ }^{126} \mathrm{MYOC}$ protein is expressed in many ocular tissues like sclera, ciliary body, retina, TM, etc. It is also expressed in a variety of nonocular tissues like myocardium, lungs, pancreas, etc. ${ }^{124}$ Despite exhaustive research, no function as of now has been attributed to this protein though it has been functionally reported to be the TIGR. The expression pattern of normal and mutant MYOC in cultured ocular and nonocular cells has been studied by Jacobson group ${ }^{127}$ with findings that normal MYOC is secreted from the cultured cells but very little or none from cells expressing five different mutant forms of MYOC. This suggests that glaucoma precipitates either due to inadequate levels of secreted MYOC or hampered TM cell function. This may presumably be caused by obstructions in the TM secretory pathway. Mature MYOC forms aggregates (multimers) secreted into trabecular extracellular matrix (ECM) interacting with various ECM components. Although mutations in CYP1B1 and myocilin (MYOC) genes have been implicated in PCG and POAG respectively, variants in both the genes have been observed in both PCG and POAG. These observations indicate an intricate and multifaceted genetics involved in PCG. In case of POAG, mutations in at least three genes, viz MYOC ${ }^{102}$ optineurin (OPTN) ${ }^{62}$ and WDR36 ${ }^{109}$, have been implicated accounting for 3 to $4 \%$ of total number of cases. In a recent study, it was found that mutations in CYP1B1 alone can be underlying cause in POAG. ${ }^{108}$ In addition, there is growing body of evidence suggesting that there exists some functional interaction between CYP1B1 and $\mathrm{MYOC}^{34}$ and this fact further lends support to the observation that PCG can also be caused by mutations in MYOC (MYOC playing the role of a potential modifier gene). ${ }^{107}$ This digenic inheritance engrossing both MYOC and CYP1B1 immediately indicates the role of MYOC in PCG (PCG in this case being allelic variant of POAG). MYOC gene, initially found to be associated with POAG was the first gene found to be implicated with any type of glaucoma. MYOC was identified in a study correlating effects of dexamethasone on cultures of TM cells. ${ }^{100}$ This gene, being the first to be associated with glaucoma, was named GLC1A $^{111,112}$ in accordance with HGO genome database nomenclature. Like CYP1B1, this gene also is expressed in many tissues of the body including the ocular ones ${ }^{113,114}$ with highest concentration in the iris, sclera and TM. ${ }^{108,112}$ It has been observed that individuals with mutations in MYOC tend to have higher IOPs implying its role in PCG. ${ }^{110,119,120}$ We have already reported five single nucleotide polymorphisms (SNPs) viz -126T > C, -83G > A, p.R76K, IVS2 + 35G > A and p.Y347Y in MYOC gene analysis in our studies on gene analysis of PCG patients. ${ }^{128}$

\section{Forkhead-related Transcription Factor C1}

FOXC1 is another potential etiological factor implicated in PCG pathogenesis. It is Forkhead-related transcription factor C1 (FOXC1 or FKHL7) and is located on p-arm of chromosome 6 (locus 6p25). See Figure 6 for a schematic representation of FOXC1 gene. FOXC1 mutations in PCG recently got attention. FOXC1 mutations were previously known to be directly involved in eye conditions collectively referred to as ASD. As TM (tissue deranged in PCG) is the part of the anterior segment, it is logical to think of its role in PCG development and pathogenesis. In our studies, we found two sequence variations viz GGC375ins and GGC447ins in FOXC1 gene in PCG patients who did not harbor mutations in CYP1B1 gene. However, it is worth mentioning that no significant correlation could be observed 


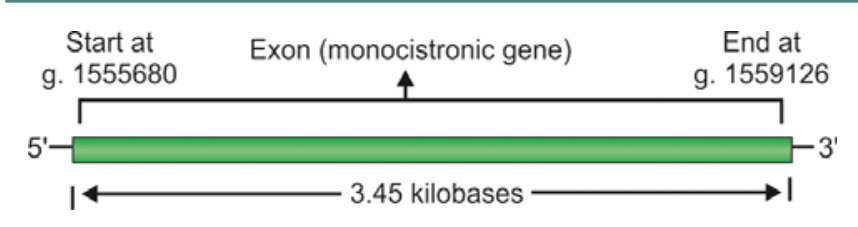

Fig. 6: Schematic representation of FOXC1 gene

between FOXC1 gene mutations and PCG in our patient cohort. ${ }^{128}$

\section{Latent Transforming Growth Factor Beta Binding Protein 2}

Linkage analysis studies of PCG in consanguineous Pakistani PCG families were recently reported and showed involvement of a new chromosomal locus adjacent to GLC3C on 14q24.2-24.3. ${ }^{3}$ The candidate gene identified was latent transforming growth factor- $\beta$-binding protein 2 (LTBP2). Figure 7 depicts a schematic diagram of this gene. Ali et al ${ }^{129}$ reported truncating mutation in this gene in PCG patients. ${ }^{129,130}$ The expression network of LTBP2 in the TM, ciliary bodies and ciliary processes ${ }^{129}$ has augmented to the complexity in the mechanism of PCG. In our studies, we also screened 54 PCG patients (who were negative for mutations in CYP1B1, MYOC and FOXC1) for mutations in LTBP2 and compared them with 50 controls. We found one intronic SNP (rs3742793) between exon VI and exon VII in 18 patients. Our studies suggest no role of mutations in LTBP2 in PCG. ${ }^{131}$

\section{Other Genes}

Other genes thought to play a role in the pathogenesis of PCG are optineurin (OPTN), WDR36, LOXL1, PAX6, PITX2, etc. but no conclusive report to confirm their role in PCG etiology has come about. However, it is sure that the more we advance in the studies of PCG; we are likely to identify many more genes having role in the etiology of this disorder as well as other related disorders termed as ASD. $^{14}$

\section{Role of Mitochondria}

Mitochondria (singular: mitochondrion) are double membrane bound, roughly sausage shaped, maternally

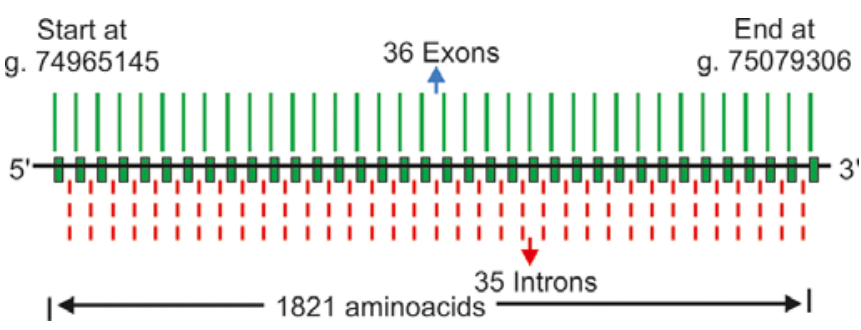

Fig. 7: Schematic representation of LTBP2 gene inherited organelles which play role in energy conversions and many other processes in the cell. They are present in all cells of the body except red blood corpuscles (RBCs). The mitochondria are semiautonomous organelles containing their own genome which is circular, double-stranded, nonhistone bound DNA coding for a variety of enzymes important in oxidative phosphorylation (OXPHOS). The human mitochondrial DNA (mt-DNA) contains 16,569 base pairs comprising 37 genes which regulate oxidative phosphorylation. Out of these 37 genes, 13 code for different subunits of the respiratory chain enzymes, 22 for different transfer RNAs (tRNAs) and the remaining 2 for ribosomal RNAs (rRNAs). The genes in mt-DNA lack introns and, therefore, do not have any intervening sequences. This is very important to note that since mitochondria are the site for electron transport chain (ETC) and their DNA is naked; it follows that mt-DNA is more prone to mutations as compared to genomic DNA. And since mitochondria are maternally inherited, vertical transmission through them is inevitable. Having primitive DNA repair mechanism ${ }^{132}$ makes mt-DNA further vulnerable to mutations often leading to cell death ${ }^{133}$ through elevation in ROS and apoptosis. A large number of human diseases have been associated with mutations in mt-DNA which range from muscular dystrophy to infertility ${ }^{134}$ but those involving ocular structures are Leber's hereditary optic neuropathy (LHON), ${ }^{135}$ pseudoexfoliation glaucoma (PEG), POAG, PACG and PCG.

There is a very high concentration of mitochondria present in the cells of optic nerve head presumably because of the requirement of higher amount of energy as compared to other tissues. Hence, the very survival of the RGCs of the optic nerve head depends on its mitochondria ${ }^{137}$ Being involved in apoptosis, calcium signaling and metabolism of reactive oxygen species (ROS); mitochondria form the imperative organelles for the survival of RGCs. It is well known that mitochondrial dysfunction/malfunction leads to increase in oxidative stress (OS) consequently ensuing damage to ETC enzymes, genomic DNA, mt-DNA and impairment in regulating calcium. This gamut of derangements results in neuronal degeneration ${ }^{138}$ finally precipitating glaucoma and other related conditions. The observation that glaucoma is accompanied by increase in OS and decrease in antioxidant activity appends further support to this idea. ${ }^{139}$ OS elevation leads to injury in the anterior segment structures of the eye. ${ }^{140}$ Furthermore, it has been observed that oxidative damage to TM is increased in glaucomatous patients ${ }^{136}$ causing increased IOP (one of the main etiological factors for PCG). Up until now, numerous studies have been published which suggest mitochondrial dysfunction as the etiological factors for various glaucomas. ${ }^{138,141,142}$ All these factors may be involved directly or indirectly in PCG. Abu Amero et al ${ }^{136}$ and Izzoti et $\mathrm{al}^{143}$ reported that mutations in mt-DNA are 
present in cases of PACG. Further, an increased frequency of mutations in mt-DNA has been reported in POAG, PACG as well PEG cases. ${ }^{144,145}$ With regards to PCG, we compared 35 PCG patients with 40 controls and screened them for mutations in mitochondrial genome by analyzing the sequences against reference sequence NC-012920. We found that $22.85 \%$ PCG patients had potentially pathogenic sequence changes in mt-DNA (as per the PolyPhen and SIFT analysis) and 57.14\% had sequence changes associated with increase in ROS. ${ }^{146}$ In these studies, the mitochondrial sequence variations in PCG patients were very high as compared to the controls, therefore, establishing mitochondria as the hot spot for etiology of PCG. In our other studies, we found the similar results. ${ }^{147}$ We have also proposed the probable mechanism for mitochondrial mutation induced TM dysgenesis. ${ }^{146}$

\section{CONCLUSION}

PCG is a complex neurodegenerative disorder with established genetic etiology. It is mainly inherited through autosomal recessive mode of inheritance. The number of chromosomal aberrations, many chromosomal loci identified and a great variety of genes involved make PCG an intricate eye condition with multifarious etiologies and consequently diverse pathogenic mechanisms. This diversity in pathogenesis accounts for the variable penetrance observed in PCG. Though a good number of studies have been published but many more rigorously investigative strategies need to be developed in order to get further insight into this blinding disorder. Many studies about the mutational spectrum of PCG in different population are being continuously reported. This will aid in correlating pathogenic mutations with the disease phenotype. The more we know about the pathogenesis of this disease, the more effectively its management strategem can be planned so that patients and their relatives are counseled with respect to risk factors. This may improve the outcome of the management regimens. Molecular evaluation of PCG is necessary and screening of high risk group can lead to good outcomes. With regards to mitochondrial mutations and increased OS, prompt antioxidant therapy and genetic counseling will and should form an essential part of glaucoma therapy in near future though gene therapy regimen is yet far from being a reality. In near future, recombinant CYP1B1 proteins might find a therapeutic role in PCG management if the CYP1B1 mutation in a patient is identified. Moreover, stem cell therapy with the correct copy of the implicated genes may be a promising regimen if the molecular mechanism of PCG is worked out in detail. Additionally, understanding the etiology, pathogenesis, mechanism and mode of PCG inheritance can help in devising counseling strategies to keep family members and children of affected members at bay. Additionally, marriage counseling can also be practiced to bring down the prevalence of PCG particularly in consanguineous societies. It is, therefore, endorsed that every ophthalmology hospital should have a separate unit for genetic evaluation, molecular workout and genetic counseling of patients suffering from PCG and other related ocular diseases.

\section{REFERENCES}

1. Jaeger, CE. A source-book of biological names and terms. Springfield (IL): Charles C Thomas; 1955. p.110.

2. Murry, JA.; Bradley, H.; Craigie, WA, et al. The Oxford English dictionary. The Clarendon Press; 1989. p. 207. (Vol. 4).

3. Sarfarazi M, Stoilov I, Schenkman JB. Genetics and biochemistry of primary congenital glaucoma. Ophthalmol Clin North Am 2003 Dec;16(4):543-554.

4. deLuise VP, Anderson DR. Primary infantile glaucoma (congenital glaucoma). Surv Ophthalmol 1983 JulAug;28(1):1-19.

5. Quigley HA. Open-angle glaucoma. N Engl J Med 1993 Apr;328(15):1097-1106.

6. Weinreb RN, Khaw PT. Primary open angle glaucoma. Lancet 2004 May;363(9422):1711-1720.

7. Westerlund, E. Clinical and genetic studies on primary glaucoma diseases. Copenhagen (Sweden): NYT Norsdic Forlag, Arnold Busck; 1947. p. 191-198.

8. Anderson, JR. Hydrophthalmia or congenital glaucoma: its causes, treatment, and outlook. London: Cambridge University Press; 1939. p. 180.

9. Vasiliou V, Gonzalez FJ. Role of CYP1B1 in glaucoma. Annu Rev Pharmacol Toxicol 2008;48:333-358.

10. Quigley HA, Broman AT. The number of people with glaucoma worldwide in 2010 and 2020. Br J Ophthalmol 2006 Mar;90(3):262-267.

11. Chandler, PA.; Grant, WM.; Epstein, DL. Chandler and Grant's glaucoma. 3rd ed. Philadelphia, PA: Lea and Febiger; 1986. p. 539.

12. Balasubramanian D. Molecular and cellular approaches to understand and treat some diseases of the eye. Curr Sci 2002;82:948-957.

13. Faiq M, Mohanty K, Dada R, Dada T. Molecular diagnostics and genetic counseling in primary congenital glaucoma. J Current Glau Prac 2013;7(1):25-35.

14. Challa P. Glaucoma genetics. Int Ophthalmol Clin 2008;48(4):73-94.

15. Barkan O. Pathogenesis of congenital glaucoma: gonioscopic and anatomic observation of the angle of the anterior chamber in the normal eye and in congenital glaucoma Am J Ophthalmol 1955 Jul;40(1):1-11.

16. Allen L, Burian HM, Braley AE. A new concept of development of anterior chamber angle; its relationship to developmental glaucoma and other structural anomalies. AMA Arch Ophthalmol 1955 Jun;53(6):783-798.

17. Maumenee EA. The pathogenesis of congenital glaucoma: a new theory. Trans Am Ophthalmol Soc 1958;56:507-570.

18. Kupfer C, Kaiser-Kupfer MI. Observations on the development of the anterior chamber angle with reference to the pathogenesis of congenital glaucomas. Am J Ophthalmol 1979 Sep;88(3 Pt 1):424-426. 
19. Anderson DR. The development of the trabecular meshwork and its abnormality in primary infantile glaucoma. Trans Am Ophthalmol Soc 1981;79:458-485.

20. Kwitko ML. The pediatric glaucomas. Int Ophthalmol Clin 1981;21(1):199-222.

21. Hoskins, HD Jr.; Kass, MA. Becker-Shaffer's diagnosis and therapy of the glaucoma. 6th ed. St Louis: CV Mosby; 1989. p. 356.

22. Kwitko, ML. Glaucoma in infants and children. New York: Appleton-Century-Crofts; 1973. p. 468.

23. Shaffer RN, Hetherington J Jr. The glaucomatous disc in infants. A suggested hypothesis for disc cupping. Trans Am Acad Ophthalmol Otolaryngol 1969 Sep-Oct;73(5):923-935.

24. Quigley HA. The pathogenesis of reversible cupping in congenital glaucoma. Am J Ophthalmol 1977 Sep;84(3):358-370.

25. Iwata K, Sobue K, Imai A, Sakurai I. On the reversibility of glaucomatous disc cupping and the visual field. Jpn J Clin Ophthalmol 1977;31:759.

26. Ho CL, Walton DS. Primary congenital glaucoma: 2004 update. J Pediatr Ophthalmol Strabismus 2004 Sep-Oct;41(5):271-288.

27. Tawara A, Inomata H, Tsukamoto S. Ciliary body band width as an indicator of goniodysgenesis. Am J Ophthalmol 1996 Dec;122(6):790-800.

28. Maul E, Strozzi L, Muñoz C, Reyes C. The outflow pathway in congenital glaucoma. Am J Ophthalmol 1980 May;89(5):667-673.

29. Tawara A, Inomata H. Congenital abnormalities of the trabecular meshwork in primary glaucoma with open angle. Glaucoma 1987;9:28-34.

30. Tawara A, Inomata H. Developmental immaturity of the trabecular meshwork in congenital glaucoma. Am J Ophthalmol 1981;92:508-525.

31. Wright JD Jr, Robb RM, Dueker DK, Boger WP 3rd. Congenital glaucoma unresponsive to conventional therapy: a clinicopathological case presentation. J Pediatr Ophthalmol Strabismus 1983 Sep-Oct;20(5):172-179.

32. Hoskins HD Jr, Shaffer RN, Hetherington J. Anatomical classification of the developmental glaucomas. Arch Ophthalmol 1984 Sep;102(9):1331-1336.

33. Shaffer, RN.; Weiss, DI. Congenital and pediatric glaucomas. St. Louis (MO): Mosby; 1970. p. 218-225.

34. Sarfarazi M, Stoilov I. Molecular genetics of primary congenital glaucoma. Eye (Lond) 2000 Jun;14(Pt 3B):422-428.

35. Benedict, TW. Abhandlungen aus dem Gebiete der Augenheilkunde. Freunde: Breslau; 1842. p. 123-132. (Ger).

36. Leske MC. The epidemiology of open-angle glaucoma: a review. Am J Epidemiol 1983 Aug;118(2):166-191.

37. Thylefors B, Negrel A. The global impact of glaucoma. Bull World Health Organ 1994;72(3):323-326.

38. Wilson, R.; Martone, J. Epidemiology of chronic open angle glaucoma. In: Ritch R, Shields M, Krupin T, editors. The glaucomas. St Louis: Mosby; 1996. p. 753-768. (Vol. 2).

39. Schinzel, A. Catalogue of unbalanced chromosomal aberrations in man. Berlin: De Gruyter; 1984. p. 720-729.

40. Broughton WL, Rosenbaum KN, Beauchamp GR. Congenital glaucoma and other ocular abnormalities associated with pericentric inversion of chromosome 11. Arch Ophthalmol 1983 Apr;101(4):594-597.

41. Stambolian D, Quinn G, Emanuel BS, Zackai E. Congenital glaucoma associated with a chromosomal abnormality. Am J Ophthalmol 1988 Nov;106(5):625-627.
42. Mandal AK, Prabhakara K, Reddy AB, Devi AR, Panicker SG. Congenital glaucoma associated with $22 \mathrm{p}+$ variant in a dysmorphic child. Indian J Ophthalmol 2003 Dec;51(4):355-357.

43. Cohn AC, Kearns LS, Savarirayan R, Ryan J, Craig JE, Mackey DA. Chromosomal abnormalities and glaucoma: a case of congenital glaucoma with trisomy 8q22-qter/ monosomy 9p23pter. Ophthalmic Genet 2005 Mar;26(1):45-53.

44. Mitchell JA, Packman S, Loughman WD, Fineman RM, Zackai E, Patil SR, Emanual B, Bartley JA, Hanson JW. Deletions of different segments of the long arm of chromosome 4. Am J Med Genet 1981;8(1):73-89.

45. Tanwar M, Dada T, Dada R. Axenfeld-Rieger syndrome associated with congenital glaucoma and cytochrome P4501B1 gene mutations. Case Rep Med 2010;2010.

46. Moore JW, Hyman S, Antonarakis SE, Mules EH, Thomas $\mathrm{GH}$. Familial isolated aniridia associated with a translocation involving chromosome 11 and 22 [t(11;22)(p13;q12.2)]. Hum Genet 1986 Apr;72(4):297-302.

47. Gong G, Kosoko-Lasaki O, Haynatzki GR, Wilson MR. Genetic dissection of myocilin glaucoma. Hum Mol Genet 2004 Apr;13(Spec No 1): 91R-102R.

48. Vincent AL, Billingsley G, Buys Y, Levin AV, Priston M, Trope G, Williams-Lyn D, Héon E. Digenic inheritance of early-onset glaucoma: CYP1B1, a potential modifier gene. Am J Hum Genet 2002 Feb;70(2):448-460.

49. Fingert JH, Stone EM, Sheffield VC, Alward WL. Myocilin glaucoma. Surv Ophthalmol 2002 Nov-Dec;47(6):547-561.

50. Geník A. Epidemiology and genetics of primary congenital glaucoma in Slovakia. Description of a form of primary congenital glaucoma in gypsies with autosomal- recessive inheritance and complete penetrance. Dev Ophthalmol 1989;16:76-115.

51. Gencik A, Gencikova A, Gerinec A. Genetic heterogeneity of congenital glaucoma. Clin Genet 1980 Apr;17(4):241-248.

52. Akarsu AN, Turacli ME, Aktan S, Barsoum-Homsy M, Chevrette L, Sayli BS, Sarfarazi M. A second locus (GLC3B) for primary congenital glaucoma (Buphthalmos) maps to the 1p36 region. Hum Mol Genet 1996 Aug;5(8):1199-1203.

53. Stoilov IR, Sarfarazi M. The third genetic locus (GLC3C) for primary congenital glaucoma (PCG) maps to chromosome 14q24.3. Invest Ophthalmol Vis Sci 2002 May;43.

54. Francois, J. Heredity in ophthalmology. St Louis (MO): CV Mosby; 1961. p. 218-225.

55. Francois J. Congenital glaucoma and its inheritance. Ophthalmologica 1980;181(2):61-73.

56. Dandona L, Williams JD, Williams BC, Rao GN. Populationbased assessment of childhood blindness in southern India. Arch Ophthalmol 1998 Apr;116(4):545-546.

57. Travers JP. The presentation of congenital glaucoma. J Pediatr Ophthalmol Strabismus 1979 Jul-Aug;16(4):241-242.

58. Gencik A, Gencikova A, Ferák V. Population genetical aspects of primary congenital glaucoma. I. Incidence, prevalence, gene frequency and age of onset. Hum Genet 1982;61(3):193-197.

59. Wagner RS. Glaucoma in children. Pediatr Clin North Am 1993 Aug;40(4):855-867.

60. Sarfarazi M, Akarsu AN, Hossain A, Turacli ME, Aktan SG, Barsoum-Homsy M, Chevrette L, Sayli BS. Assignment of a locus (GLC3A) for primary congenital glaucoma (Buphthalmos) to 2p21 and evidence for genetic heterogeneity. Genomics 1995 Nov;30(2):171-177. 
61. Plásilová M, Feráková E, Kádasi L, Poláková H, Gerinec A, Ott J, Ferák V. Linkage of autosomal recessive primary congenital glaucoma to GLC3A locus in Roms (Gypsies) from Slovakia. Hum Hered 1998 Jan-Feb;48(1):30-33.

62. Bejjani BA, Lewis RA, Tomey KF, Anderson KL, Dueker DK, Jabak M, Astle WF, Otterud B, Leppert M, Lupski JR. Mutations in CYP1B1, the gene for cytochrome P4501B1, are the predominant cause of primary congenital glaucoma in Saudi Arabia. Am J Hum Genet 1998 Feb;62(2):325-333.

63. Jay M, Rice NS. Genetic implications of congenital glaucoma. Metab Ophthalmol 1978;2:257-258.

64. N Vithana E, Aung T. Exploring the basis of sex bias in primary congenital glaucoma. J Ophthalmic Vis Res 2009 Apr;4(2):73-74.

65. Dickens, CS.; Hoskins, HD. Congenital glaucoma. In: Ritch R, Shields MB, Krupin T, editors. The Glaucomas. St Louis: Mosby; 1996. p. 727-749.

66. Komai, T. Pedigrees of hereditary diseases. Genetica: Kyoto; 1934. p. 79-125.

67. Nakajima, A.; Fujiki, K.; Tanable, U. Genetics of buphthalmos (7th Congr). Karachi: Asia Pacific Acad Ophthalmol; 1979.

68. Briard ML, Feingold J, Kaplan J, Bonaiti C, Aron JJ, Blanck MF, Delthil S, Frezal J. The genetics of congenital glaucoma: a study of 231 cases. J Genet Hum 1976 Nov;24 Suppl:107123. (Fre).

69. Vogt A. Vererbter hydrothalmus beim kaninchen. Klin Augenheilkd 1919;63:233. (Ger).

70. Franceschetti, A. Die vererbung von augenleiden kurzes handbuch der ophthalmologie. Berlin: Springer; 1930. p. 631855, 89.

71. Geri G. Considerization e ricerche sull eredita dell idroftalmia nel coniglio. Ricerca Sci 1954;24:2299-2315.

72. Gelatt KN, Peiffer RL Jr, Gwin RM, Sauk JJ Jr. Glaucoma in the beagle. Trans Sect Ophthalmol Am Acad Ophthalmol Otolaryngol 1976 Jul-Aug;81:636-644.

73. Magnussen K. Beitrag zur Genetik des Glaukoms beim kaninchen. Albrecht von Graefes Archiv für Ophthalmologie 1961;164(2):197-219.

74. François GJ. L 'hérédité en ophtalmologie (glaucoma congenital). Paris: Masson; 1958. p. 246-255.

75. Gianferrari L, Cresseri A, Maltarello A. Ricerche sulla ereditarieta dell'idroftalmo e della cataratta congenita in paesi delle prealpi orobiche. Acta Genet Med Gemellol 1954;3:1-15.

76. Waardenburg, PJ.; Francheshetti, A.; Klein, D. In: Genetics in ophthalmology (hydrophthalmia). Van Gorcum, Assen 1961. p. 681-683.

77. Belkin M, Olover M, Cohen T. Congenital glaucoma with different clinical manifestations in members of one sibship. J Pediat Ophthal 1972;8:266-269.

78. Merin S, Morin D. Heredity of congenital glaucoma. Br J Ophthalmol 1972 May;56(5):414-417.

79. Cuendet JR. Inheritance counseling in eye disease. Eugen 1957;4:139-147.

80. Cresseri A, Beccherle C. Ricerche sull'eredità dell'idroftalmo in un paese della Valsassina. Rendiconti dell'Istituto lombardo di scienze e lettere. Clin Sci 1944-1945;78:472-492.

81. Leighton DA, Phillips CI. Infantile glaucoma. Steroid testing in parents of affected children. Br J Ophthalmol 1970 Jan;54(1):27-30.
82. van der Helm F. Hydrophthalmia and its treatment. A general study based on 630 cases in the Netherlands. Bibl Ophthalmol 1963;61:1-64.

83. Burow B, Thiele U. Genetische beratung beieblichen augenkrankheiten. Graefes Arch Ophthalmol 1972;188:307-321.

84. Demenais F, Bonaïti C, Briard ML, Feingold J, Frézal J. Congenital glaucoma: genetic models. Hum Genet 1979 Feb;46(3):305-317.

85. Jensen SJ, Sulman EP, Maris JM, Matise TC, Vojta PJ, Barrett JC, Brodeur GM, White PS. An integrated transcript map of human chromosome 1p35-p36. Genomics 1997 May;42(1):126-136.

86. Denton P, Lennon F, Valentine M, Rao N, Stajich J, Look AT, Pericak-Vance MA, Vance JM. Genetic and physical mapping of the chromosome 1 p36 region surrounding the CharcotMarie-Tooth disease (CMT) type 2A locus. Cytogenet Cell Genet 1996;72:147.

87. Gonzalez FJ. The molecular biology of cytochrome P450s. Pharmacol Rev 1988 Dec;40(4):243-288.

88. Nelson DR, Zeldin DC, Hoffman SM, Maltais LJ, Wain HM, Nebert DW. Comparison of cytochrome P450 (CYP) genes from the mouse and human genomes, including nomenclature recommendations for genes, pseudogenes and alternative-splice variants. Pharmacogenetics 2004 Jan;14(1):1-18.

89. Sutter TR, Tang YM, Hayes CL, Wo YY, Jabs EW, Li X, Yin $\mathrm{H}$, Cody CW, Greenlee WF. Complete cDNA sequence of a human dioxin-inducible mRNA identifies a new gene subfamily of cytochrome P450 that maps to chromosome 2. J Biol Chem 1994 May;269(18):13092-13099.

90. Savas U, Bhattacharyya KK, Christou M, Alexander DL, Jefcoate CR. Mouse cytochrome P-450EF, representative of a new $1 \mathrm{~B}$ subfamily of cytochrome P-450s. Cloning, sequence determination and tissue expression. J Biol Chem 1994 May;269(21):14905-14911.

91. Bhattacharyya KK, Brake PB, Eltom SE, Otto SA, Jefcoate CR. Identification of a rat adrenal cytochrome P450 active in polycyclic hydrocarbon metabolism as rat CYP1B1. Demonstration of a unique tissue-specific pattern of hormonal and aryl hydrocarbon receptor-linked regulation. J Biol Chem 1995 May;270(19):11595-11602.

92. Otto S, Marcus C, Pidgeon C, Jefcoate CR. A novel adrenocorticotropin-inducible cytochrome P450 from rat adrenal microsomes catalyzes polycyclic aromatic hydrocarbon metabolism. Endocrinology 1991 Aug;129(2):970-982.

93. Walker NJ, Gastel JA, Costa LT, Clark GC, Lucier W, Sutter TR. Rat CYP1B1: An adrenal cytochrome P450 that exhibits sex-dependent expression in livers and kidneys of TCDDtreated animals. Carcinogenesis 1995 Jun;16(6):1319-1327.

94. Tang YM, Wo YY, Stewart J, Hawkins AL, Griffin CA, Sutter TR, Greenlee WF. Isolation and characterization of the human cytochrome P450 CYP1B1 gene. J Biol Chem 1994 Nov;271(45):28324-28330.

95. Muskhelishvili L, Thompson PA, Kusewitt DF, Wang C, Kadlubar FF. In situ hybridization and immunohistochemical analysis of cytochrome P4501B1 expression in human normal tissues. J Histochem Cytochem 2001 Feb;49(2):229-236.

96. Chen H, Howald WN, Juchau MR. Biosynthesis of all-transretinoic acid from all-trans-retinol: catalysis of all-trans-retinol oxidation by human P-450 cytochromes. Drug Metab Dispos 2000 Mar;28(3):315-322.

97. Swindell EC, Eichele G. Retinoid metabolizing enzymes in development. Biofactors 1999;10(2-3):85-89. 
98. Nebert DW. Drug Metabolism. Growth signal pathways. Nature 1990 Oct;347(6295):709-710.

99. Nebert DW. Proposed role of drug-metabolizing enzymes: regulation of steady state levels of the ligands that effect growth, homeostasis, differentiation, and neuroendocrine functions. Mol Endocrinol 1991 Sep;5(9):1203-1214.

100. Sarfarazi M. Recent advances in molecular genetics of glaucomas. Hum Mol Genet 1997;6(10):1667-1677.

101. Choudhary D, Jansson I, Rezaul K, Han DK, Sarfarazi M, Schenkman JB. Cyp1b1 protein in the mouse eye during development: an immunohistochemical study. Drug Metab Dispos 2007 Jun;35(6):987-994.

102. Stoilov I, Akarsu AN, Sarfarazi M. Identification of three different truncating mutations in cytochrome P4501B1 (CYP1B1) as the principal cause of primary congenital glaucoma (Buphthalmos) in families linked to the GLC3A locus on chromosome 2p21. Hum Mol Genet 1997 Apr;6(4):641-647.

103. Li N, Zhou Y, Du L, Wei M, Chen X. Overview of Cytochrome P450 1B1 gene mutations in patients with primary congenital glaucoma. Exp Eye Res 2011 Nov;93(5):572-579.

104. Tanwar M, Dada T, Sihota R, Das TK, Yadav U, Dada R. Mutation spectrum of CYP1B1 in North Indian congenital glaucoma patients. Mol Vis 2009 Jun;15:1200-1209.

105. Tanwar M, Dada T, Sihota R, Dada R. Identification of four novel cytochrome P4501B1 mutations (p.I94X, p.H279D, p.Q340H, and p.K433K) in primary congenital glaucoma patients. Mol Vis 2009 Dec;15:2926-2937.

106. Stoilov I, Akarsu AN, Alozie I, Child A, Barsoum-Homsy M, Turacli ME, Or M, Lewis RA, Ozdemir N, Brice G, et al. Sequence analysis and homology modeling suggest that primary congenital glaucoma on 2p21 results from mutations disrupting either the hinge region or the conserved core structures of cytochrome P4501B1. Am J Hum Genet 1998 Mar;62(3):573-584.

107. Kakiuchi-Matsumoto T, Isashiki Y, Ohba N, Kimura K, Sonoda S, Unoki K. Cytochrome P450 1B1 gene mutations in Japanese patients with primary congenital glaucoma(1). Am J Ophthalmol 2001 Mar;131(3):345-350.

108. Bejjani BA, Stockton DW, Lewis RA, Tomey KF, Dueker DK, Jabak M, Astle WF, Lupski JR. Multiple CYP1B1 mutations and incomplete penetrance in an inbred population segregating primary congenital glaucoma suggest frequent de novo events and a dominant modifier locus. Hum Mol Genet 2000 Feb;9(3):367-374.

109. Kakiuchi T, Isashiki Y, Nakao K, Sonoda S, Kimura K, Ohba N. A novel truncating mutation of cytochrome P4501B1 (CYP1B1) gene in primary infantile glaucoma. Am J Ophthalmol 1999 Sep;128(3):370-372.

110. Mashima Y, Suzuki Y, Sergeev Y, Ohtake Y, Tanino T, Kimura I, Miyata H, Aihara M, Tanihara H, Inatani M, et al. Novel cytochrome P4501B1 (CYP1B1) gene mutations in Japanese patients with primary congenital glaucoma. Invest Ophthalmol Vis Sci 2001 Sep;42(10):2211-2216.

111. Panicker SG, Reddy AB, Mandal AK, Ahmed N, Nagarajaram HA, Hasnain SE, Balasubramanian D. Identification of novel mutations causing familial primary congenital glaucoma in Indian pedigrees. Invest Ophthalmol Vis Sci 2002 May;43(5):1358-1366.

112. Stoilov IR, Costa VP, Vasconcellos JP, Melo MB, Betinjane AJ, Carani JC, Oltrogge EV, Sarfarazi M. Molecular genetics of primary congenital glaucoma in Brazil. Invest Ophthalmol Vis Sci 2002 Jun;43(6):1820-1827.
113. Colomb E, Kaplan J, Garchon HJ. Novel cytochrome P450 1B1 (CYP1B1) mutations in patients with primary congenital glaucoma in France. Hum Mutat 2003 Dec;22(6):496.

114. Lewis DF, Gillam EM, Everett SA, Shimada T. Molecular modeling of human CYP1B1 substrate interactions and investigation of allelic variant effects on metabolism. Chem Biol Interact 2003 Jun;145(3):281-295.

115. Plasilova M, Stoilov I, Sarfarazi M, Kádasi L, Feráková E, Ferák V. Identification of single ancestral CYP1B1 mutation in Slovak Gypsies (Roms) affected with primary congenital glaucoma. J Med Genet 1999 Apr;36(4):290-294.

116. Panicker SG, Mandal AK, Reddy AB, Gothwal VK, Hasnain SE. Correlations of genotype with phenotype in Indian patients with primary congenital glaucoma. Invest Ophthalmol Vis Sci 2004 Apr;45(4):1149-1156.

117. Civan MM, Macknight AD. The ins and outs of aqueous humor secretion. Exp Eye Res 2004 Mar;78(3):625-631.

118. Libby RT, Smith RS, Savinova OV, Zabaleta A, Martin JE, Gonzalez FJ, John SW. Modification of ocular structures in mouse developmental glaucoma models by tyrosinase. Science 2003 Mar;299(5612):1578-1581.

119. Buters JT, Sakai S, Richter T, Pineau T, Alexander DL, Savas U, Doehmer J, Ward JM, Jefcoate CR, Gonzalez FJ. Cytochrome P450 CYP1B1 determines susceptibility to 7,12dimethylbenz[a]anthracene-induced lymphomas. Proc Natl Acad Sci USA 1999 Mar;96(5):1977-1982.

120. van Dorp DB, Delleman JW, Loewer-Sieger DH. Oculocutaneous albinism and anterior chamber cleavage malformations. Not a coincidence. Clin Genet 1984 Nov;26(5):440-444.

121. Mckay BS, Roberts BC, Stamer WD. Myocilin: A molecular address for nascent junctions (ARVO Abstract). Invest Ophthalmol Vis Sci 2000;41:843.

122. Polansky JR, Fauss DJ, Chen P, Chen H, Lütjen-Drecoll E, Johnson D, Kurtz RM, Ma ZD, Bloom E, Nguyen TD. Cellular pharmacology and molecular biology of the trabecular meshwork inducible glucocorticoid response gene product. Ophthalmologica 1997;211(3):126-139.

123. Stone EM, Fingert JH, Alward WL, Nguyen TD, Polansky JR, Sunden SL, Nishimura D, Clark AF, Nystuen A,Nichols BE, et al. Identification of a gene that causes primary open angle glaucoma. Science 1997 Jan;275(5300):668-670.

124. Kubota R, Noda S, Wang Y, Minoshima S, Asakawa S, Kudoh J, Mashima Y, Oguchi Y, Shimizu N. A novel myosin-like protein (myocilin) expressed in the connecting cilium of the photoreceptor: molecular cloning, tissue expression and chromosomal mapping. Genomics 1997 May;41(3):360-369.

125. Nguyen TD, Chen P, Huang WD, Chen H, Johnson D, Polansky JR. Gene structure and properties of TIGR, an olfactomedinrelated glycoprotein cloned from glucocorticoid-induced trabecular meshwork cells. J Biol Chem 1998 Mar;273(11):6341-6350.

126. Subramanian V, Garcia A, Sekowski A, Brasaemle DL. Hydrophobic sequences target and anchor perilipin A to lipid droplets. J Lipid Res 2004 Nov;45(11):1983-1991.

127. Jacobson N, Andrews M, Shepard AR, Nishimura D, Searby C, Fingert JH, Hageman G, Mullins R, Davidson BL, Kwon $\mathrm{YH}$, et al. Non-secretion of mutant proteins of the glaucoma gene myocilin in cultured trabecular meshwork cells and in aqueous humor. Hum Mol Genet 2001 Jan;10(2):117-125.

128. Tanwar M, Kumar M, Dada T, Sihota R, Dada R. MYOC and FOXC1 gene analysis in primary congenital glaucoma. Mol Vis 2010 Oct;16:1996-2006. 
129. Ali M, McKibbin M, Booth A, Parry DA, Jain P, Riazuddin SA, Hejtmancik JF, Khan SN, Firasat S, Shires M, et al. Null mutations in LTBP2 cause primary congenital glaucoma. Am J Hum Genet 2009 May;84(5):664-671.

130. Narooie-Nejad M, Paylakhi SH, Shojaee S, Fazlali Z, Rezaei Kanavi M, Nilforushan N, Yazdani S, Babrzadeh F,Suri F, Ronaghi $\mathrm{M}$, et al. Loss of function mutations in the gene encoding latent transforming growth factor beta binding protein 2, LTBP2, cause primary congenital glaucoma. Hum Mol Genet 2009 Oct;18(20):3969-3977.

131. Mohanty K, Tanwar M, Dada R, Dada T. Screening of the LTBP2 gene in a north Indian population with primary congenital glaucoma. Mol Vis 2013;19:78-84.

132. Brown WM, George M Jr, Wilson AC. Rapid evolution of animal mitochondrial DNA. Proc Natl Acad Sci USA 1979 Apr;76(4):1967-1971.

133. Richter C. Oxidative stress, mitochondria and apoptosis. Restor Neurol Neurosci 1998 Jun;12(2-3):59-62.

134. Howell N. LHON and other optic nerve atrophies: the mitochondrial connection. Dev Ophthalmol 2003;37:94-108.

135. Abu-Amero KK, Bosley TM. Mitochondrial abnormalities in patients with LHON-like optic neuropathies. Invest Ophthalmol Vis Sci 2006 Oct;47(10):4211-4220.

136. Abu-Amero KK, Morales J, Bosley TM. Mitochondrial abnormalities in patients with primary open angle glaucoma. Invest Ophthalmol Vis Sci 2006 Jun;47(6):2533-2541.

137. Barron MJ, Griffiths P, Turnbull DM, Bates D, Nichols P. The distributions of mitochondria and sodium channels reflect the specific energy requirements and conduction properties of the human optic nerve head. Br J Ophthalmol 2004 Feb;88(2):286-290.

138. Tezel G, Yang X. Caspase-independent component of retinal ganglion cell death, in vitro. Invest Ophthalmol Vis Sci 2004 Nov;45(11):4049-4059.

139. Zanon-Moreno V, Marco-Ventura P, Lleo-Perez A, PonsVazquez S, Garcia-Medina JJ, Vinuesa-Silva I, Moreno-Nadal MA, Pinazo-Duran MD. Oxidative stress in primary open-angle glaucoma. J Glaucoma 2008 Jun-Jul;17(4):263-268.

140. Seppet E, Gruno M, Peetsalu A, Gizatullina Z, Nguyen HP, Vielhaber S, Wussling MH, Trumbeckaite S,Arandarcikaite O, Jerzembeck D, et al. Mitochondria and energetic depression in cell pathophysiology. Int J Mol Sci 2009 May;10(5):2252-2303.

141. Tatton WG, Chalmers-Redman RM, Sud A, Podos SM, Mittag TW. Maintaining mitochondrial membrane impermeability. An opportunity for new therapy in glaucoma? Surv Ophthalmol 2001 May;45(Suppl 3):277S-296S.

142. Mittag TW, Danias J, Pohorenec G, Yuan HM, Burakgazi E, Chalmers-Redman R, Podos SM, Tatton WG. Retinal damage after 3 to 4 months of elevated intraocular pressure in a rat glaucoma model. Invest Ophthalmol Vis Sci 2000 Oct;41(11):3451-3459.

143. Izzotti A, Bagnis A, Sacca SC. The role of oxidative stress in glaucoma. Mutat Res 2006 Mar;612(2):105-114.

144. Abu-Amero KK, Morales J, Osman MN, Bosley TM. Nuclear and mitochondrial analysis of patients with primary angleclosure glaucoma. Invest Ophthalmol Vis Sci 2007 Dec;48(12):5591-5596.

145. Abu-Amero KK, Bosley TM, Morales J. Analysis of nuclear and mitochondrial genes in patients with pseudoexfoliation glaucoma. Mol Vis 2008 Jan;14:29-36.

146. Tanwar M, Dada T, Sihota R, Dada R. Mitochondrial DNA analysis in primary congenital glaucoma. Mol Vis 2010 Mar;16:518-533.
147. Kumar M, Tanwar M, Faiq MA, Pani J, Shamsi MB, Dada T, Dada R. Mitochondrial DNA nucleotide changes in primary congenital glaucoma patients. Mol Vis 2013;19:220-230.

148. Hollander DA, Sarfarazi M, Stoilov I, Wood IS, Fredrick DR, Alvarado JA. Genotype and phenotype correlations in congenital glaucoma: CYP1B1 mutations, goniodysgenesis and clinical characteristics. Am J Ophthalmol 2006 Dec;142(6):993-1004.

149. Sena DF, Finzi S, Rodgers K, Del Bono E, Haines JL, Wiggs JL. Founder mutations of CYP1B1 gene in patients with congenital glaucoma from the United States and Brazil. J Med Genet 2004 Jan;41(1):e6.

150. Della Paolera M, de Vasconcellos JP, Umbelino CC, Kasahara N, Rocha MN, Richeti F, Costa VP, Tavares A, de Melo MB. CYP1B1 gene analysis in primary congenital glaucoma Brazilian patients: novel mutations and association with poor prognosis. J Glaucoma 2010 Mar;19(3):176-182.

151. Dimasi DP, Hewitt AW, Straga T, Pater J, MacKinnon JR, Elder JE, Casey T, Mackey DA, Craig JE. Prevalence of CYP1B1 mutations in Australian patients with primary congenital glaucoma. Clin Genet 2007 Sep;72(3): 255-260.

152. Martin SN, Sutherland J, Levin AV, Klose R, Priston M, Heon E. Molecular characterization of congenital glaucoma in a consanguineous Canadian community: a step towards preventing glaucoma related blindness. J Med Genet 2000 Jun;37(6):422-427.

153. Jiang FG, Liu XW, Hou HP. Analysis of the CYP1B1 gene mutation in primary congenital glaucoma patients of Hubei Han nationality. Zhonghua Yan Ke Za Zhi 2007 Sep;43(9):779783. (Chn).

154. Huang LN, Ji PX, Cheng HB. Initial study in CYP1B1 gene of primary congenital glaucoma. Chin J Pract Ophthalmol 2007;25:280-282.

155. Chen Y, Jiang D, Yu L, Katz B, Zhang K, Wan B, Sun X. CYP1B1 and MYOC mutations in 116 Chinese patients with primary congenital glaucoma. Arch Ophthalmol 2008 Oct;126(10):1443-1447.

156. Yang M, Guo X, Liu X, Shen H, Jia X, Xiao X, Li S, Fang S, Zhang Q. Investigation of CYP1B1 mutations in Chinese patients with primary congenital glaucoma. Mol Vis 2009;15:432-437.

157. Huang JF, Zhou J, Wang H, Chen D, Zeng LP, Tong JB, Xia $\mathrm{XB}$, Hu ZM. A novel mutation of CYP1B1 gene in primary congenital glaucoma. Zhonghua Yan Ke Za Zhi 2009 Oct;45(10):875-878. (Chin).

158. Curry SM, Daou AG, Hermanns P, Molinari A, Lewis RA, Bejjani BA. Cytochrome P450 1B1 mutations cause only part of primary congenital glaucoma in Ecuador. Ophthalmic Genet 2004 Mar;25(1):3-9.

159. Weisschuh N, Wolf C, Wissinger B, Gramer E. A clinical and molecular genetic study of German patients with primary congenital glaucoma. Am J Ophthalmol 2009 Apr;147(4):744-753.

160. Sivadorai P, Cherninkova S, Bouwer S, Kamenarova K, Angelicheva D, Seeman P, Hollingsworth K, Mihaylova V, Oscar A, Dimitrova G, et al. Genetic heterogeneity and minor CYP1B1 involvement in the molecular basis of primary congenital glaucoma in Gypsies. Clin Genet 2008 Jul;74(1):82-87.

161. Reddy AB, Panicker SG, Mandal AK, Hasnain SE, Balasubramanian D. Identification of R368H as a predominant CYP1B1 allele causing primary congenital glaucoma in Indian patients. Invest Ophthalmol Vis Sci 2003 Oct;44(10):4200-4203.

162. Chakrabarti S, Komatireddy S, Mandal AK, Balasubramanian D. Gene symbol: CYP1B1. Disease: glaucoma, primary congenital. Hum Genet 2003 Nov;113(6):556. 
163. Reddy AB, Kaur K, Mandal AK, Panicker SG, Thomas R, Hasnain SE, Balasubramanian D, Chakrabarti S. Mutation spectrum of the CYP1B1 gene in Indian primary congenital glaucoma patients. Mol Vis 2004 Sep;10:696-702.

164. Nirmaladevi J, Karthiyayini T, Kumaramanickavel G. Gene symbol: CYP1B1. Disease: Primary congenital glaucoma. Accession \#Hd0515. Hum Genet 2006 Feb;118(6):775.

165. Nirmaladevi J, Karthiyayini T, Kumaramanickavel G. Gene symbol: CYP1B1. Disease: Primary congenital glaucoma. Accession \#Hm0544. Hum Genet 2006 Feb;118(6):779.

166. Ramprasad VL, George RJ, Sripriya S, Nirmaladevi J, Vijaya L, Kumaramanickavel G. Molecular genetic analysis of a consanguineous south Indian family with congenital glaucoma: relevance of genetic testing and counseling. Ophthalmic Genet 2007 Mar;28(1):17-24.

167. Sitorus R, Ardjo SM, Lorenz B, Preising M. CYP1B1 gene analysis in primary congenital glaucoma in Indonesian and European patients. J Med Genet 2003 Jan;40(1):e9.

168. Chitsazian F, Tusi BK, Elahi E, Saroei HA, Sanati MH, Yazdani S, Pakravan M, Nilforooshan N, Eslami Y, Mehrjerdi MA, et al. CYP1B1 mutation profile of Iranian primary congenital glaucoma patients and associated haplotypes. J Mol Diagn 2007 Jul;9(3):382-393.

169. Suri F, Yazdani S, Narooie-Nejhad M, Zargar SJ, Paylakhi SH, Zeinali S, Pakravan M, Elahi E. Variable expressivity and high penetrance of CYP1B1 mutations associated with primary congenital glaucoma. Ophthalmology 2009 Nov;116(11):2101-2109.

170. Bar-Yosef U, Levy J, Elbedour K, Ofir R, Carmi R, Birk OS. Congenital glaucoma: CYP1B1 mutations in Israeli Bedouin kindreds. J Glaucoma 2010 Jan;19(1):35-38.

171. Fuse N, Miyazawa A, Takahashi K, Noro M, Nakazawa T, Nishida K. Mutation spectrum of the CYP1B1 gene for congenital glaucoma in the Japanese population. Jpn J Ophthalmol 2010 Jan;54(1):1-6.

172. Alfadhli S, Behbehani A, Elshafey A, Abdelmoaty S, Al-Awadi S. Molecular and clinical evaluation of primary congenital glaucoma in Kuwait. Am J Ophthalmol 2006 Mar;141(3):512-516.

173. Messina-Baas OM, Gonzalez-Huerta LM, Chima-Galan C, KofmanAlfaro SH, Rivera-Vega MR, Babayan-Mena I, Cuevas-Covarrubias SA. Molecular analysis of the CYP1B1 gene: Identification of novel truncating mutations in patients with primary congenital glaucoma. Ophthalmic Res 2007;39(1):17-23.

174. Zenteno JC, Hernandez-Merino E, Mejia-Lopez H, MatiasFlorentino M, Michel N, Elizondo-Olascoaga C, Korder-Ortega V, Casab-Rueda H, Garcia-Ortiz JE. Contribution of CYP1B1 mutations and founder effect to primary congenital glaucoma in Mexico. J Glaucoma 2008 Apr-May;17(3):189-192.

175. Belmouden A, Melki R, Hamdani M, Zaghloul K, Amraoui A, Nadifi $\mathrm{S}$, Akhayat $\mathrm{O}$, Garchon HJ. A novel frameshift founder mutation in the cytochrome $\mathrm{P} 4501 \mathrm{~B} 1$ (CYP1B1) gene is associated with primary congenital glaucoma in Morocco. Clin Genet 2002 Oct;62(4): 334-339.

176. Hilal L, Boutayeb S, Serrou A, Refass-Buret L, Shisseh H, Bencherifa F, El Mzibri M, Benazzouz B, Berraho A. Screening of CYP1B1 and MYOC in Moroccan families with primary congenital glaucoma: three novel mutations in CYP1B1. Mol Vis $2010 \mathrm{Jul} ; 16: 1215-1226$.

177. Brinkmann JF, Ottenheim CP, Zegers RH, de Jong PT, Bergen AA. Gene symbol: CYP1B1. Disease: Glaucoma, primary congenital. Accession \#Hd0513. Hum Genet 2006 Feb;118(6):775.
178. Brinkmann JF, Ottenheim CP, Zegers RH, de Jong PT, Bergen AA. Gene symbol: CYP1B1. Disease: Glaucoma, primary congenital. Accession \#Hm0541. Hum Genet 2006 Feb;118(6):779.

179. El-Gayar S, Ganesh A, Chavarria-Soley G, Al-Zuhaibi S, Al-Mjeni R, Raeburn S, Bialasiewicz AA. Molecular analysis of CYP1B1 in Omani patients with primary congenital glaucoma: a pilot study. Mol Vis 2009 Jul;15:1325-1331.

180. Firasat S, Riazuddin SA, Khan SN, Riazuddin S. Novel CYP1B1 mutations in consanguineous Pakistani families with primary congenital glaucoma. Mol Vis 2008;14:2002-2009.

181. Chavarria-Soley G, Michels-Rautenstrauss K, Pasutto F, Flikier D, Flikier P, Cirak S, Bejjani B, Winters DL, Lewis RA, Mardin C, et al. Primary congenital glaucoma and Rieger's anomaly: extended haplotypes reveal founder effects for eight distinct CYP1B1 mutations. Mol Vis 2006 May;12:523-531.

182. El-Ashry MF, Abd El-Aziz MM, Bhattacharya SS. A clinical and molecular genetic study of Egyptian and Saudi Arabian patients with primary congenital glaucoma (PCG). J Glaucoma 2007 Jan;16(1):104-111.

183. Campos-Mollo E, Lopez-Garrido MP, Blanco-Marchite C, GarciaFeijoo J, Peralta J, Belmonte-Martinez J, Ayuso C, Escribano J. CYP1B1 mutations in Spanish patients with primary congenital glaucoma: phenotypic and functional variability. Mol Vis 2009;15: 417-431.

184. Lopez-Garrido MP, Campos-Mollo E, Harto MA, Escribano J. Primary congenital glaucoma caused by the homozygous F261L CYP1B1 mutation and paternal isodisomy of chromosome 2. Clin Genet 2009 Dec;76(6):552-557.

185. Michels-Rautenstrauss KG, Mardin CY, Zenker M, Jordan N, Gusek-Schneider GC, Rautenstrauss BW. Primary congenital glaucoma: Three case reports on novel mutations and combinations of mutations in the GLC3A (CYP1B1) gene. J Glaucoma 2001 Aug;10(4):354-357.

186. Bagiyeva S, Marfany G, Gonzalez-Angulo O, Gonzalez-Duarte R. Mutational screening of CYP1B1 in Turkish PCG families and functional analyses of newly detected mutations. Mol Vis 2007 Aug; 13:1458-1468.

187. Strom CM, Strom S, Redman Ms J, Sun W. Prenatal diagnosis for primary congenital glaucoma (buphthalmous). Prenat Diagn 2006 Sep;26(9):877.

\footnotetext{
${ }^{1,4}$ Pursuing Doctorate, ${ }^{2}$ Resident, ${ }^{3}$ Additional Professor

${ }^{5}$ Professor, ${ }^{6}$ Additional Professor

1,2,4,6 Dr Rajendra Prasad Centre for Ophthalmic Sciences, All India Institute of Medical Sciences, New Delhi, India

${ }^{3}$ Department of Anatomy, Laboratory for Molecular Reproduction and Genetics, All India Institute of Medical Sciences, New Delhi, India

${ }^{5}$ Medical Biotechnology Laboratory, Dr BR Ambedkar Centre for Biomedical Research, University of Delhi, New Delhi, India

Corresponding Author: Tanuj Dada, Additional Professor Dr Rajendra Prasad Centre for Ophthalmic Sciences, All India Institute of Medical Sciences, New Delhi-110029, India, e-mail: tanujdada@gmail.com
} 